This document is confidential and is proprietary to the American Chemical Society and its authors. Do not copy or disclose without written permission. If you have received this item in error, notify the sender and delete all copies.

\title{
(Z)-Oxopropene-1,3-diyl, a Linker for the Conjugation of the Thiol Group of Cysteine with Amino-Derivatized Drugs
}

\begin{tabular}{|c|c|}
\hline Journal: & The Journal of Organic Chemistry \\
\hline Manuscript ID & Draft \\
\hline Manuscript Type: & Note \\
\hline $\begin{array}{r}\text { Date Submitted by the } \\
\text { Author: }\end{array}$ & $\mathrm{n} / \mathrm{a}$ \\
\hline Complete List of Authors: & $\begin{array}{l}\text { Vilarrasa, Jaume; Universitat de Barcelona, Organic Chemistry Section } \\
\text { Petit, Elena; Universitat de Barcelona, Organic Chemistry Section } \\
\text { Bosch, Lluis; Universitat de Barcelona, Organic Chemistry Section } \\
\text { Costa, Anna; Universitat de Barcelona, Organic Chemistry Section }\end{array}$ \\
\hline
\end{tabular}

\section{SCHOLARONE Manuscripts}




\title{
(Z)-Oxopropene-1,3-diyl, a Linker for the Conjugation of the Thiol Group of Cysteine with Amino-Derivatized Drugs
}

\author{
Elena Petit, Lluís Bosch, Anna M. Costa, ${ }^{*}$ and Jaume Vilarrasa* \\ Organic Chemistry Section, Facultat de Química, Universitat de Barcelona, Diagonal 645, 08028 Barcelona, Catalonia, Spain
}

\section{- Supporting Information}

\begin{abstract}
The handicaps of the maleimides, the most commonly used reagents to link thiol groups (of Cys) to drugs, fluorescent labels, etc., prompted us to revise and develop an alternative, based on the known thia-Michael addition to activated triple bonds, which could be useful under physiological conditions. A drug with an amino group was converted into its propynamide and, in aqueous media at $37^{\circ} \mathrm{C}$ and $\mathrm{pH} 7.4$, Cys derivatives were added, to afford rapidly the $Z$ adduct. This chemical linker (the oxopropene-1,3-diyl group) showed advantages, in terms of following the reaction course: no diastereomers were formed; excellent selectivity ( $\mathrm{S}^{-}$vs. $\mathrm{NH}_{2}$, even at $\mathrm{pH} 10.0$ and 12.0 ), without secondary reactions; no exchange with other thiols; and no

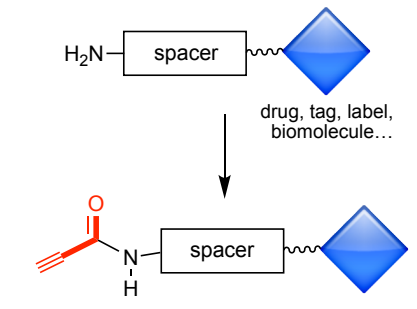

Conventional cancer treatments that use cytotoxic compounds cause serious side effects due to their lack of selectivity for tumor cells. As known, a very promising strategy to avoid or alleviate these drawbacks is to conjugate cytotoxic drugs with antibodies (targeted therapy). ${ }^{1}$ The preparation of antibody-drug conjugates (ADCs) requires efficient and reliable linkage protocols. ${ }^{2}$ Most ADCs currently on the market (4 are currently FDA-approved) and in clinical development use the Michael addition reaction of a native or geneticallyengineered Cys in the antibody to a maleimide group to form the conjugate. ${ }^{3}$ This transformation is widely used because the reaction is quantitative and fast under physiological conditions; however, the adducts may undergo thiol exchange in vivo causing off-site cytotoxicity and compromising the efficacy of the conjugate. ${ }^{4,5}$ Other Cys conjugations have been reported (Scheme 1$)^{6}$, including the addition to electron-deficient alkynes. ${ }^{7}$

Our long-standing interest in the conjugate addition of several nucleophiles to activated triple bonds ${ }^{8}$ has recently led us to examine the possibility of going a step further: whether, under real physiological conditions, these reagents — specifically, propynamides—will or will not be useful to bind or link (as a linchpin or link pin) thiols and amines (Scheme 2). In other words, from our own work ${ }^{8}$ and from that of our colleagues Arjona and Plumet, ${ }^{9}$ we were aware that $\mathrm{HC} \equiv \mathrm{C}-\mathrm{EWG}$ compounds with strong EWGs such as $\mathrm{SO}_{2} \mathrm{R}$ and COOR are capable of reacting at rt even with very weak nucleophiles, in the presence of suitable catalysts. We did not know, however, if the reactions of Cys with $\mathrm{HC} \equiv \mathrm{C}-\mathrm{CONHR}$ would be sufficiently quick, complete, and stereoselective in aqueous solvents, without any additive, or if the 


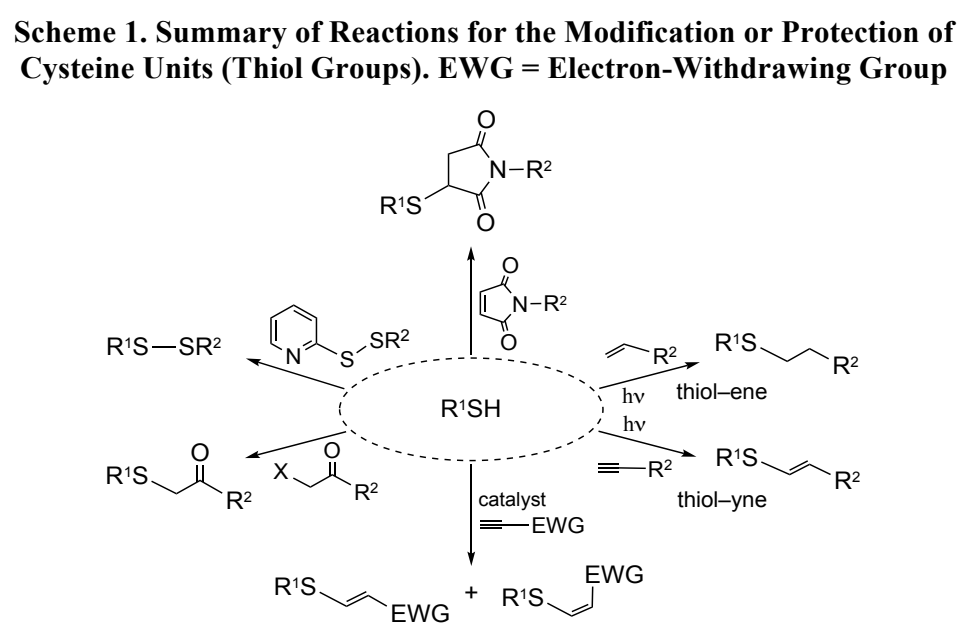

addition products (adducts) would be stable enough in physiological media and in the presence of other thiols. The carboxamido groups $\left(\mathrm{CONHR}\right.$ and $\left.\mathrm{CONR}_{2}\right)$, although weaker EWGs, are much more resistant to chemical hydrolysis than ester groups, and so could function as a suitable point of attachment for any drug "decorated" with amino groups. In this Note we report our results in this direction.

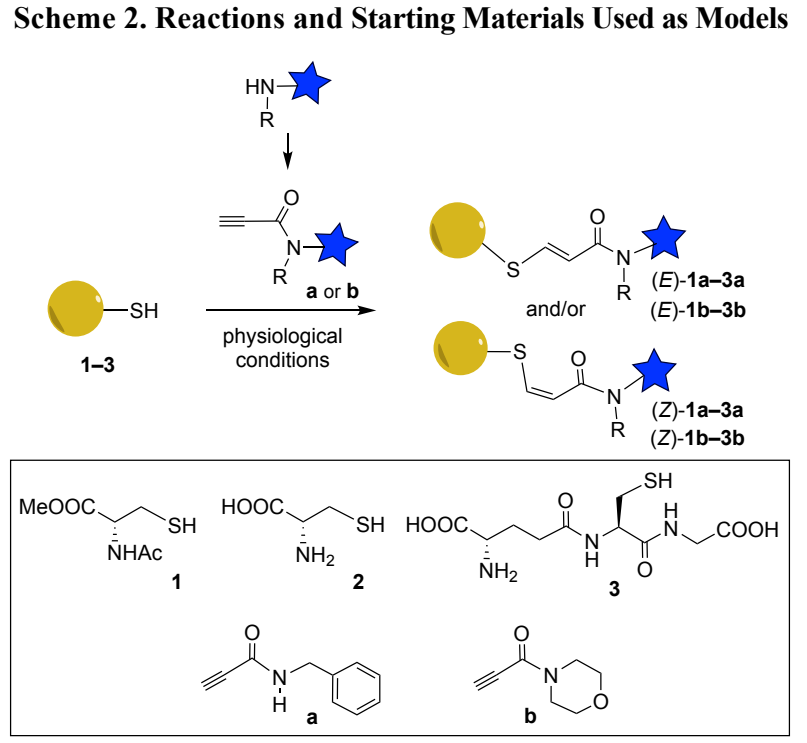

The acylation of a primary or secondary amine with commercially available reagents such as propynoic acid (also known as propiolic or propargylic acid) and 3-trimethylsilylpropynoic acid (followed by desilylation), in the presence of a coupling agent (for example, dicyclohexylcarbodiimide, DCC, or any of its analogs) are well-known reactions. ${ }^{10}$ In the direct reaction, variable yields are usually reported because the product may undergo, either in situ or during the workup, the addition of the amine and/or any nucleophile present. With the C-silylated derivative, two steps are necessary-coupling in the presence of any dehydrating agent, followed by smooth, well-known desilylation protocols - but both yields are excellent $(>90 \%)$ and the process may be carried out in one pot. We 
1

2

3

4

5

6

7

8

9

will not comment further on the standard preparations of the starting propynamides (Scheme 2), since this Note is tightly focused on their reactions with thiols in aqueous media.

Reactions of a protected cysteine (1), cysteine itself (Cys, 2) and a cysteine-containing pseudo-tripeptide (the natural antioxidant glutathione, 3) with $N$-substituted propynamide a and $N, N$-disubstituted propynamide $\mathbf{b}$ were examined in water or in a mixture of water and a miscible organic solvent. "Water" means here a phosphate-buffered aqueous solution of $\mathrm{pH}$ 7.4. A summary is shown in Table 1. Although the reactions in buffered water were complete, the use of ${ }^{t} \mathrm{BuOH}-\mathrm{H}_{2} \mathrm{O}, \mathrm{EtOH}-\mathrm{H}_{2} \mathrm{O}$, or THF- $\mathrm{H}_{2} \mathrm{O}$ was also studied due to the poor solubility of a and $\mathbf{b}$ in buffered water. For the linkage of two water-soluble biomolecules, the addition of an alcohol or THF will be unnecessary.

Table 1. Screening the Reaction Conditions for the Addition of the Thiol Group of Cysteines to Propynamides a and $\mathrm{b}^{a}$

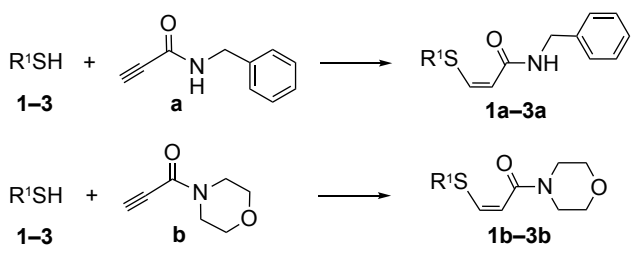

\begin{tabular}{|c|c|c|c|c|c|c|c|c|}
\hline entry & thiol & alkyne & solvent(s) & $\mathrm{pH}$ & $\mathrm{T}\left({ }^{\circ} \mathrm{C}\right)$ & $\mathrm{t}(\min )$ & yield $(\%)^{a}$ & $Z / E^{b}$ \\
\hline 1 & 1 & $\mathbf{a}$ & $\mathrm{H}_{2} \mathrm{O}$ or ${ }^{t} \mathrm{BuOH}-\mathrm{H}_{2} \mathrm{O}$ & 6.0 & $\mathrm{rt}$ & 1,000 & $1 \mathrm{a}, 5$ & $50: 50$ \\
\hline 2 & 1 & $\mathbf{a}$ & $\mathrm{H}_{2} \mathrm{O}$ & 7.4 & $\mathrm{rt}$ & 70 & $1 \mathbf{a}, 93$ & $98: 2$ \\
\hline 3 & 1 & $\mathbf{a}$ & $\mathrm{H}_{2} \mathrm{O}$ & 7.4 & 37 & 60 & $1 a, 94$ & $98: 2$ \\
\hline 4 & 1 & $\mathbf{a}$ & $\mathrm{EtOH}-\mathrm{H}_{2} \mathrm{O}, 1: 1$ & 7.4 & 37 & 50 & 1b, 98 & $93: 7$ \\
\hline 5 & 1 & b & $\mathrm{H}_{2} \mathrm{O}$ & 7.4 & 37 & 50 & 1b, 98 & $>99: 1^{d}$ \\
\hline 6 & 1 & $\mathbf{b}$ & ${ }^{t} \mathrm{BuOH}-\mathrm{H}_{2} \mathrm{O}, 1: 1$ & 7.4 & 37 & 40 & 1b, 98 & $>99: 1^{d}$ \\
\hline 7 & 2 & $\mathbf{a}$ & $\mathrm{H}_{2} \mathrm{O}$ & 7.4 & $\mathrm{rt}$ & 70 & 2a, 92 & $98: 2$ \\
\hline 8 & 2 & $\mathbf{a}$ & ${ }^{t} \mathrm{BuOH}-\mathrm{H}_{2} \mathrm{O}, 1: 1$ & 7.4 & 37 & 60 & $2 a, 96$ & $>99: 1^{d}$ \\
\hline 9 & 2 & $\mathbf{a}$ & $\mathrm{THF}-\mathrm{H}_{2} \mathrm{O}, 1: 1$ & 7.4 & 37 & 60 & $\mathbf{2 a}, 92$ & $85: 15$ \\
\hline 10 & 2 & $\mathbf{a}$ & $\mathrm{THF}-\mathrm{H}_{2} \mathrm{O}, 1: 3^{c}$ & 7.4 & 37 & 60 & $2 a, 94$ & $98: 2$ \\
\hline 11 & 2 & $\mathbf{a}$ & ${ }^{t} \mathrm{BuOH}-\mathrm{H}_{2} \mathrm{O}, 1: 1$ & 10.0 & 37 & 30 & $2 a, 96$ & $>99: 1^{d}$ \\
\hline 12 & 2 & $\mathbf{a}$ & $\mathrm{H}_{2} \mathrm{O}$ & 12.0 & 37 & 30 & $\mathbf{2 a}, 92$ & $88: 12$ \\
\hline 13 & 2 & $\mathbf{b}$ & $\mathrm{H}_{2} \mathrm{O}$ & 7.4 & 37 & 40 & $\mathbf{2 b}, 99$ & $95: 5$ \\
\hline 14 & 2 & $\mathbf{b}$ & $\mathrm{THF}-\mathrm{H}_{2} \mathrm{O}, 1: 1$ & 7.4 & 37 & 40 & $\mathbf{2 b}, 96$ & $65: 35$ \\
\hline 15 & 2 & $\mathbf{b}$ & $\mathrm{THF}-\mathrm{H}_{2} \mathrm{O}, 1: 3^{c}$ & 7.4 & 37 & 40 & $\mathbf{2 b}, 97$ & $>99: 1^{d}$ \\
\hline 16 & 2 & $\mathbf{b}$ & ${ }^{t} \mathrm{BuOH}-\mathrm{H}_{2} \mathrm{O}, 1: 1$ & 7.4 & 37 & 40 & 2b, 97 & $>99: 1^{d}$ \\
\hline 17 & 3 & $\mathbf{a}$ & ${ }^{t} \mathrm{BuOH}-\mathrm{H}_{2} \mathrm{O}, 1: 1$ & 7.4 & 37 & 60 & 3a, 93 & $>99: 1^{d}$ \\
\hline 18 & 3 & $\mathbf{a}$ & $\mathrm{THF}-\mathrm{H}_{2} \mathrm{O}, 1: 3^{c}$ & 10.0 & 37 & 40 & $3 a, 95$ & $95: 5$ \\
\hline 19 & 3 & $\mathbf{b}$ & $\mathrm{H}_{2} \mathrm{O}$ & 7.4 & 37 & 40 & $3 b, 95$ & $95: 5$ \\
\hline 20 & 3 & $\mathbf{b}$ & ${ }^{t} \mathrm{BuOH}-\mathrm{H}_{2} \mathrm{O}, 1: 1$ & 7.4 & 37 & 40 & 3b, 98 & $>99: 1^{d}$ \\
\hline 21 & 3 & $\mathbf{b}$ & $\mathrm{THF}-\mathrm{H}_{2} \mathrm{O}, 1: 3^{c}$ & 10.0 & 37 & 40 & $\mathbf{3 b}, 93$ & $95: 5$ \\
\hline
\end{tabular}

${ }^{a}$ Thiols 1-3 (0.20-0.50 mmol) were dissolved in phosphate-buffered solutions $(2.5 \mathrm{~mL})$ under $\mathrm{N}_{2}$; in the cases of 2 and 3, solid $\mathrm{K}_{2} \mathrm{HPO}_{4}$ was added until the $\mathrm{pH}$ value was 7.40 (pHmeter). These solutions were then slowly added, over 10 min, to the propynamides $(0.22-0.55 \mathrm{mmol})$ in $2.5 \mathrm{~mL}$ of either $\mathrm{H}_{2} \mathrm{O}, \mathrm{EtOH},{ }^{t} \mathrm{BuOH}$, THF or aqueous THF. Phosphate buffer was not added in entry 1 , but the $\mathrm{pH}$ was continuously measured (pHmeter, 6.0). In other cases the $\mathrm{pH}$ was adjusted to 10.0 by addition of $\mathrm{K}_{2} \mathrm{CO}_{3}$ and to 12.0 with $\mathrm{K}_{3} \mathrm{PO}_{4}$. Stirring under $\mathrm{N}_{2}$ at $\mathrm{rt}$ or in a bath at $37 \pm 1{ }^{\circ} \mathrm{C}$ was maintained for further 10-60 $\mathrm{min}$. Isolated yields are given for $\mathbf{1 a}$ and $\mathbf{1 b}$, before removing small amounts of isomers $E$ (when necessary) by column chromatography. Yields before recrystallization are given for zwitterions 2a,b and 3a,b (see Experimental Section). ${ }^{b} Z / E$ ratios were determined by ${ }^{1} \mathrm{H}$ NMR before purification. ${ }^{c}$ The propynamide was dissolved in buffered water + THF to ensure that $\mathrm{H}_{2} \mathrm{O}$ predominated in the medium from the very beginning. ${ }^{d}$ The minor isomer was not detected during and after the reaction, even when increasing the number of scans and expanding the spectra. 
As shown in Table 1, the reactions of 1-3 with $\mathbf{a}$ and $\mathbf{b}$ were completed in 40-70 min even at concentrations of the reactants $\leq 0.1$ $\mathrm{M}$, either at $\mathrm{rt}$ or $37^{\circ} \mathrm{C}$. Excellent isolated yields of the desired adducts were obtained (by TLC chromatography and NMR the conversions were complete). At $0.5 \mathrm{M}$ concentrations, only a few minutes were required, as expected, but we were interested in examining the reactions under dilute conditions for the potential application of the protocol to mAbs or to molecular scaffolds.

The $Z$ diastereomer was always obtained with excellent diastereoselectivity, except for two cases: in entries 9 and 14, when a nonhydroxylic solvent such as THF was used. However, it was sufficient to perform the addition with propynamides a and $\mathbf{b}$ dissolved in a mixture of THF and buffered water to avoid the formation of isomer $E$. In other words, in buffered water or a hydroxylic solvent as the medium throughout the reaction time, the protonation of the addition intermediate is so rapid that isomer $\mathrm{Z}$ largely predominates. The 1:1 ${ }^{\mathrm{t}} \mathrm{BuOH}$-buffered $\mathrm{H}_{2} \mathrm{O}$ mixture was the medium of choice with both the $\mathrm{N}$-substituted and $\mathrm{N}, \mathrm{N}$-disubstituted carboxamides.

No catalyst or additives were necessary for the reactions in Table 1 . They did not progress in water at $\mathrm{pH}<6$, but in water at $\mathrm{pH} 7.4$, the thiol protons are sufficiently acid $\left(\mathrm{p} K_{\mathrm{a}} \text { of } \mathrm{Cys}=8.18 \text {, general } \mathrm{p} K_{\mathrm{a}} \text { range in proteins } \approx 7.4-9.1\right)^{11}$ to be in equilibrium with a certain percentage of thiolate ion, which attacks the most electron-deficient carbon of the activated triple bond. The rapid protonation of the anionic adduct ${ }^{7 \mathrm{a}}$ leads to a well-known trans-addition, in such a way that the substituents of the double bond turn out to be cis. This is an advantage of all thia-Michael additions in relation to other click reactions for thiols, since (potentially) toxic catalysts and/or waterinsoluble additives can be avoided. This is in sharp contrast to parallel conjugate additions of thiols in organic solvents, which require catalysis by nucleophiles and which preferentially lead to $E$ isomers. ${ }^{8,9}$ For example, $\mathbf{1}$ and $\mathbf{a}$, treated with catalytic amounts of DABCO in anhydrous $\mathrm{CH}_{3} \mathrm{CN}$ at rt, quantitatively gave the $E$ isomer (data not included in Table 1, for the sake of simplicity), which showed olefin protons at $\delta \mathrm{H} 5.92$ and $7.46 \mathrm{ppm},{ }^{3} J=14.8 \mathrm{~Hz}$ and olefin carbons at $\delta \mathrm{C} 118.1$ and $141.6 \mathrm{ppm}$.

What matters here is that the competition between the thiol and the amino group of $\mathbf{2}$ or $\mathbf{3}$ was won by the first. It reacted with complete selectivity with the alkyne, even when using water at $\mathrm{pH} 10.0$ (entries 11,18 , and 21 ): no products derived from the attack of the amino group were detected in any case. ${ }^{7 \mathrm{a}}$ In one experiment at $\mathrm{pH} 12.0$ with $\mathbf{2}$ and a (entry 12), we once again observed that only the thiolate ion was added to the triple bond (formation of 2a, no attack through the amino group). In summary, the thiolate ion is more reactive than the amino group, in conjugate additions to propynamides. The reaction of 2 with commercially available $N$-benzylmaleimide $[N$-(phenylmethyl)maleimide, $\mathbf{c}]$, at $\mathrm{pH} 10.0$ and $\mathrm{pH}$ 12.0, also afforded only the products arising from the thiolate addition, but the product, $\mathbf{2 c}$, underwent ring opening.

Isomers $Z$ of $\mathbf{1 a - 3 a}$ and $\mathbf{1 b}-\mathbf{3 b}$ are readily characterized by the diagnostic NMR signals of the double bonds that are formed. In contrast, adducts of 1-3 with $N$-benzylmaleimide (c), which we prepared and isolated for the sake of comparison, were mixtures of diastereoisomers, as expected. This unnecessarily complicates the NMR spectra and chromatograms, as well as the future evaluation of the homogeneity of the samples arising from the functionalization of peptides and molecular scaffolds or platforms with several thiol groups (the characterization of which is then limited to the use of mass spectrometry). In Figure 1 representative spectra of 1a and $\mathbf{1 c}$ are compared (for expanded, high-quality spectra see Supporting Information). The spectra of 1a, in the left column, are very clear with relevant protons in the double bond region where overlap with 
1

2

3

4

5

6

7

8

other signals, apart from broad $\mathrm{NH}$ signals of $\mathrm{CONH}$, seldom occurs in protein chemistry. Also, the relevant carbon atoms of the double bond appear downfield and upfield, respectively, to standard aromatic and olefinic carbons. In short, there are only two proton signals in the ${ }^{1} \mathrm{H}$ NMR spectrum and only two signals in the ${ }^{13} \mathrm{C}$ NMR spectrum. In sharp contrast, in the case of succinimide 1c, see the right column, there are two sets of 3'- $\mathrm{CH}$ signals while protons 4'- $\mathrm{CH}_{2}$ (in duplicate, 4 diastereotopic hydrogens, 2 diastereotopic $\mathrm{C}$ atoms) appear in the same 3.5-2.5 ppm and 34-37 ppm regions as the signals of 3- $\mathrm{CH}_{2}$ (of Cys). Thus, if we had to prepare a molecular scaffold with 4 thiol groups, which by treatment with maleimide-type acceptors could afford mixtures of up to 8 succinimides, NMR spectroscopy would be useless for the product characterization.

$\mathrm{MeOOC}$

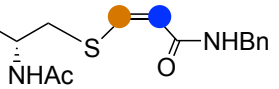

(Z)-1a
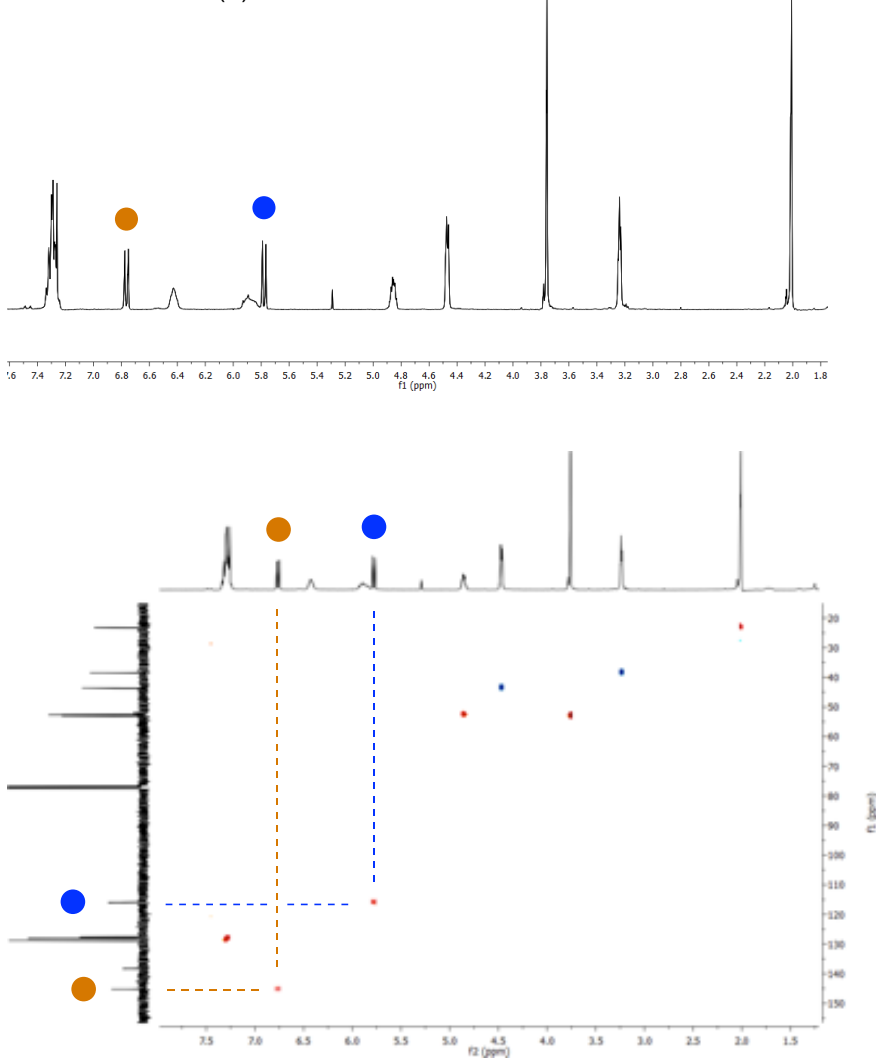

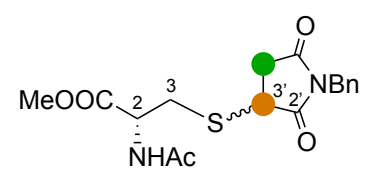

$1 c$

$\left(2 R, 3^{\prime} R\right)$ and $\left(2 R, 3^{\prime} S\right)$
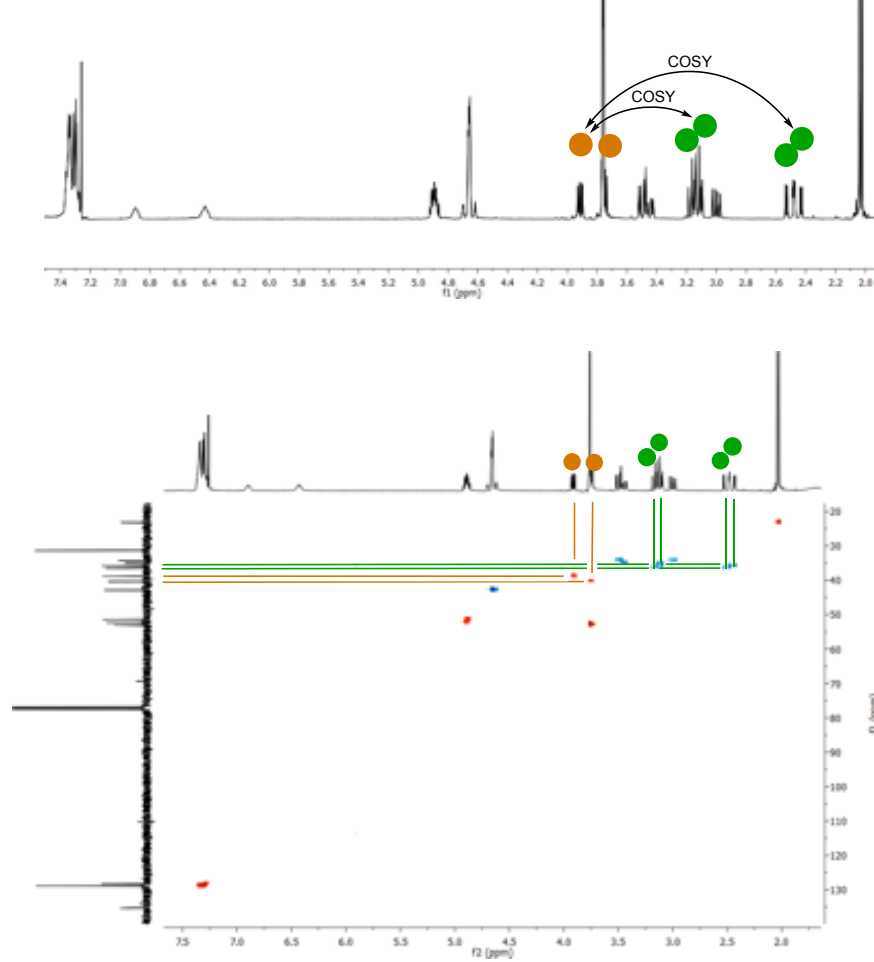

Figure 1. ${ }^{1} \mathrm{H}$ and HSQC NMR Spectra of 1a (Left Column) and 1c (Right Column)

The reactions of $\mathbf{1}$ with a and $\mathbf{c}$ were also followed by ${ }^{1} \mathrm{H}$ NMR in $\mathrm{D}_{2} \mathrm{O}\left(\mathrm{pH} 7.4\right.$, by addition of a small amount of $\left.\mathrm{K}_{2} \mathrm{HPO}_{4}\right)$. They are summarized in Scheme 3 (top). Incorporation of deuterium in (Z)-1a was not surprising. Incorporation of deuterium in 1c (a nearly 1:1 diastereomeric mixture) was also evident: one of each 4'- $\mathrm{CH}_{2}$ protons of the succinimide or pyrrolidine-2,5-dione rings "disappeared" and the ${ }^{13} \mathrm{C}$ NMR spectra also confirmed the monodeuteration of the $\mathrm{CH}_{2}$ groups. ${ }^{12}$ Few minutes later, a set of trideuterated isotopomers $\left(\mathbf{1}\right.$ - $\left.d_{3}\right)$ had been formed due to the exchange of the relatively more acidic hydrogen H3' with the solvent, as shown in Scheme 3 (bottom). This 
exchange at position 3' was also observed when 1c, prepared in ${ }^{t} \mathrm{BuOH}-\mathrm{H}_{2} \mathrm{O}$, was simply dissolved in $\mathrm{D}_{2} \mathrm{O}$ to register its $\mathrm{NMR}$ spectra. This also happened when 1c was dissolved in hot $\mathrm{CD}_{3} \mathrm{OD}: 86 \%$ of deuteration on $\mathrm{C} 3^{\prime}$ was noted within $1 \mathrm{~h}$ at $60{ }^{\circ} \mathrm{C}$ without any additive. The deuteration of such a position was also very rapid with $\mathbf{2 c}$ and $\mathbf{3 c}$, each a mixture of diastereomers as well, when dissolved in $\mathrm{D}_{2} \mathrm{O}$, which was warmed for few minutes to favor the dissolution of the samples. However, in $\mathrm{D}_{2} \mathrm{O}$ with a drop of TFA no exchange was observed. In other words, not only are the succinimides such as 1c-3c labile in basic media, with ring opening, and sensitive to exchange reactions with other thiols ${ }^{4,5}$ (either by elimination-addition reactions or by direct substitutions), but there are rapid proton exchanges at the S$\mathrm{CH}-\mathrm{CO}$ moiety, probably via its enolate-like anion at $\mathrm{pH} \geq 7.4$.

Carboxamides 1a, 1b, 2a, 2b, 3a, and $\mathbf{3 b}$ are reported here for the first time. They have been fully characterized. Their ${ }^{1} \mathrm{H}$ and ${ }^{13} \mathrm{C}$ NMR spectra and relevant 2D NMR spectra are provided as Supporting Information.

\section{Scheme 3. Deuterated Species Observed in $\mathrm{D}_{2} \mathrm{O}$}

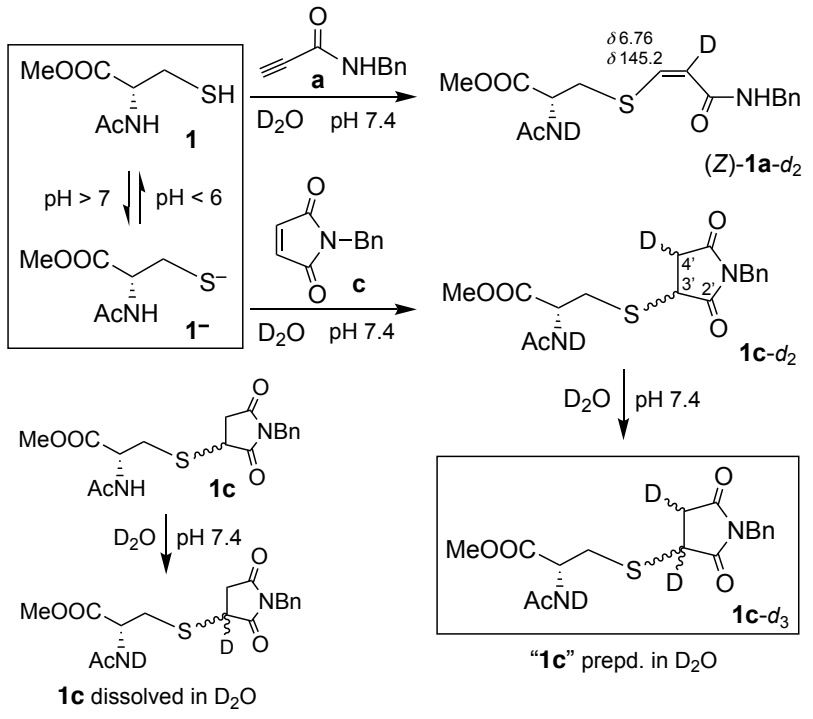

An alternative to the preparation of the thia-Michael adducts just described is the addition-elimination reaction of thiols with $\beta$ halopropenamides ( $\beta$-haloacrylamides), a known reaction, ${ }^{13}$ but not reported in aqueous solvents or with biologically relevant thiols. ${ }^{14}$ When $\mathbf{1}-$ 3 were treated with $\beta$-haloacrylamides $\mathbf{d}$ and $\mathbf{e}$ under physiological conditions, the expected adducts were obtained in excellent yields and with complete retention of the stereochemistry of the double bond (Scheme 4, top). Addition of 1-3 to propenamide (acrylamide) $\mathbf{f}$ also took place under the same conditions, but more slowly. In fact, the qualitative order of reactivity, as observed by ${ }^{1} \mathrm{H}$ NMR, was: propynamide a $>>(Z)$ iodopropenamide $\mathbf{d}>(E)$-iodopropenamide $\mathbf{e}>>$ propenamide $\mathbf{g}$ (Scheme 4, bottom). Thus, activated triple bonds react with nucleophiles more rapidly than similarly activated double bonds, which is a textbook statement. Nevertheless, maleimide c (with two CO groups activating the double bond) reacted more quickly than propynamide a under identical physiological conditions. ${ }^{15}$ 
1

2

3

4

5

6

7

8

9

In our hands, from qualitative competition experiments at $\mathrm{pH} 7.4$ as always, in ${ }^{t} \mathrm{BuOH}-\mathrm{H}_{2} \mathrm{O}$ to ensure that all the starting compounds remain soluble, maleimide $\mathbf{c}$ appeared to be more electrophilic than ethyl propynoate $(\mathrm{HC} \equiv \mathrm{C}-\mathrm{COOEt})$ and morpholine amide of propynoic acid (b), which is slightly more reactive than a. However, maleimide $\mathbf{c}$ is less reactive than tosylacetylene ${ }^{9 a}$ and ethynyl phenyl sulfone ("besylacetylene", $\left.\mathrm{HC} \equiv \mathrm{C}-\mathrm{SO}_{2} \mathrm{Ph}\right) .{ }^{8 \mathrm{f}}$ High reactivity is very often incompatible with the chemoselectivity that is desired, in agreement with the reactivity-selectivity principle, so we were not interested in examining a variety of $\mathrm{HC} \equiv \mathrm{C}-\mathrm{EWG}$ with very strong EWGs.

Scheme 4. Evaluation of Alternatives to Propynamides a and b
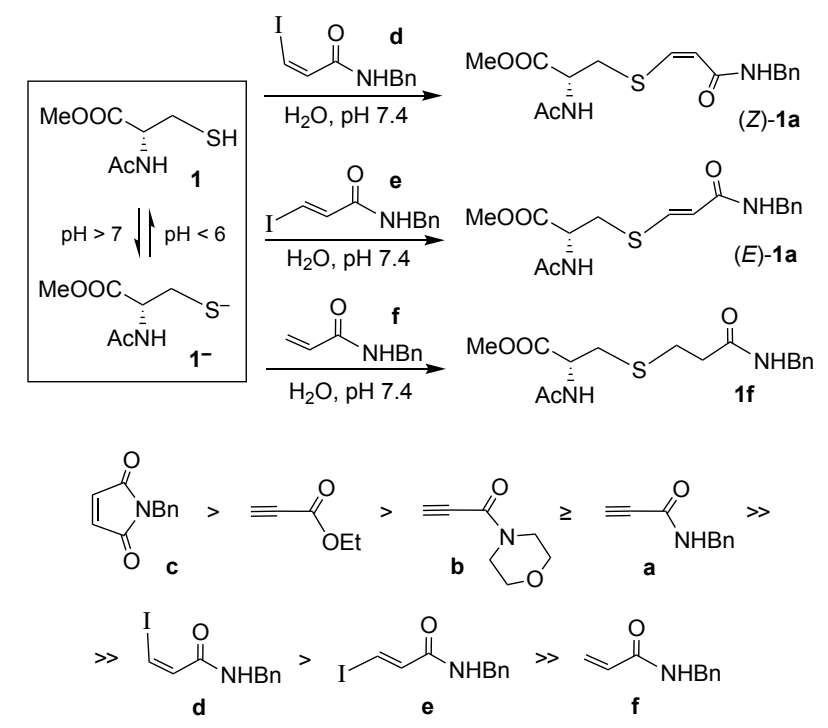

A final issue concerns the stability of the carbonylvinylsulfide moiety, that is, of the S-linker bond, in the presence of other thiols and under acidic or basic conditions. Several experiments were carried out in this regard. By addition to $\mathbf{1 a}$ of an equivalent amount of $\mathbf{1}$ in ${ }^{t} \mathrm{BuOH}-\mathrm{H}_{2} \mathrm{O}$ at $\mathrm{pH} 7.4$ and $37^{\circ} \mathrm{C}$, with overnight stirring, no change was observed (no formation of dithioacetal, no isomerization at all to the $E$ isomer). ${ }^{16} \mathrm{We}$ had to add 4 equiv of $\mathbf{1}$, under these conditions, to observe a $25 \%$ of $Z$-to- $E$ isomerization and nothing else. Furthermore, addition to ( $Z$ )-1b, again in ${ }^{t} \mathrm{BuOH}-\mathrm{H}_{2} \mathrm{O}$ at $\mathrm{pH} 10.0$ and $37^{\circ} \mathrm{C}$, with overnight stirring, of 1 or 4 equiv of 12-dodecanethiol did not produce any change. Also, the $\mathrm{S}-\mathrm{CH}=\mathrm{CH}-\mathrm{CO}$ linkage turned out to be stable in acidic media, since the dissolution of $\mathbf{1 a}-\mathbf{3 a}$ and $\mathbf{1 b}-\mathbf{3 b}$ in water with $10 \%$ TFA, again overnight in a bath at $37^{\circ} \mathrm{C}$, did not cleave the linker (only hydrolysis of the ester group of $\mathbf{1 a}$ and $\mathbf{1 b}$ was observed). Some NMR spectra of $\mathbf{2 a}$ and 3a were registered in TFA without decomposition. Moreover, in a basic medium, addition of $10 \%$ of $\mathrm{Et}_{3} \mathrm{~N}$ to ${ }^{t} \mathrm{BuOH}^{-} \mathrm{H}_{2} \mathrm{O}$ solutions of $\mathbf{1 a}$ and overnight stirring, as always at $37^{\circ} \mathrm{C}$, did not affect the linker (only the ester group was saponified, as expected). This is not the case with 1c, the succinimide ring of which was cleaved under these conditions, in agreement with literature reports. ${ }^{4,5}$ We also observed that succinimide 2c, once dissolved in DMSO- $d_{6}$, was cleaved within $1 \mathrm{~h}$ by addition of $\mathrm{K}_{2} \mathrm{HPO}_{4} / \mathrm{D}_{2} \mathrm{O}$. To summarize, in contrast to the 3-(thioalkoxy)succinimide moieties, the $\mathrm{S}-\mathrm{CH}=\mathrm{CH}-\mathrm{CO}$ moiety appeared to be reasonably stable in the presence of thiols, acids and bases. 
Last but not least, as a proof of concept, we started synthesis of a more complex model from a known carboxylic acid, ${ }^{17}$ a derivative of a drug candidate (see Scheme 5) that was available in our lab in connection with a different project and which we prepared in accordance with the reported procedure. ${ }^{17}$ Although the details will be reported elsewhere, we can advance that we attached this carboxyl derivative to commercially available 3-azidopropylamina (3-azido-1-propanamine), which may be considered the simplest model of a spacer. After reduction of the azido group to amine (by catalytic hydrogenation, but other already classical routes were also successful ${ }^{18}$ ), conversion to its propynamide $\mathbf{g}$ (see Scheme 5) was effected by standard procedures mentioned in the introduction. We treated $\mathbf{1}$ and $\mathbf{2}$ with $\mathbf{g}$ in ${ }^{\mathrm{t}} \mathrm{BuOH}-$ $\mathrm{H}_{2} \mathrm{O}$ at $\mathrm{pH} 7.4$ and $37^{\circ} \mathrm{C}$, also at approximately $0.1 \mathrm{M}$ concentrations of the reactants. The reactions were completed within $2 \mathrm{~h}$, to afford enantiopure 1g and 2g, which were characterized by NMR and MS as usual (see Experimental Section).

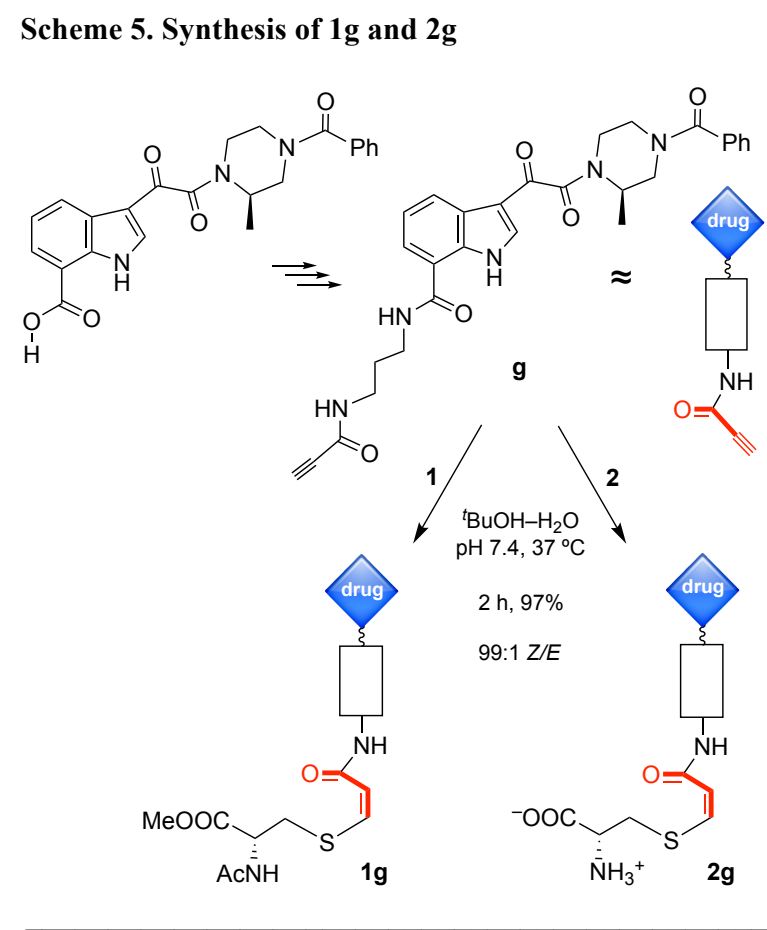

In conclusion, from a simple conjugate addition - a known thia-Michael reaction - we have developed a practical linker for the bioconjugation of Cys derivatives under physiological conditions, without additives, with substrates containing a propynamide group (that is, a moderately activated triple bond, which has advantages, as shown herein). It can be considered another click reaction. We recognize that the application of these new methodological results, which complement those reported in the chemistry literature, to real ADCs is still far off and that the stability in vivo of the linker has yet to be studied; these studies were outside the scope of the present work, but they are our next objective.

\section{EXPERIMENTAL SECTION}

General Methods. Unless specified otherwise, all starting materials and reagents were obtained from commercial suppliers and used without further purification. All reactions were conducted in oven-dried glassware, under nitrogen, in anhydrous solvents, which were dried and distilled before use 
according to standard procedures. Analytical thin-layer chromatography (TLC) was performed on $0.25 \mathrm{~mm}$ silica gel plates $\left(\mathrm{F}_{254}\right)$. Retention factors $\left(R_{f}\right)$ are approximate. Flash column chromatography was performed on silica gel $60(35-70 \mu \mathrm{m})$. Melting points or decomposition temperatures were obtained with a Gallenkamp apparatus. ${ }^{1} \mathrm{H}$ NMR spectra were recorded in $\mathrm{CDCl}_{3}$ on $400 \mathrm{MHz}$ spectrometers; chemical shifts are given in ppm with the solvent resonance as the internal standard (residual $\mathrm{CHCl}_{3}$ in $\mathrm{CDCl}_{3}, \delta 7.26 \mathrm{ppm}$; residual $\mathrm{CD}_{3} \mathrm{SOCHD}_{2}$ in DMSO- $d_{6}, \delta 2.50 \mathrm{ppm} ; \mathrm{DOH}$ in $\mathrm{D}_{2} \mathrm{O}, \delta 4.79$ ppm). Data are reported as usual: chemical shift in $\delta$, multiplicity $(\mathrm{s}=$ singlet, $\mathrm{d}=$ doublet, $\mathrm{t}=$ triplet, $\mathrm{q}=$ quartet, quin $=$ quintet, br $\mathrm{s}=$ broad singlet, $\mathrm{m}$ $=$ multiplet), coupling constants in $\mathrm{Hz}$, and integration. For cysteine derivatives $\mathbf{2 a}-\mathbf{c}$ and $\mathbf{3 a}-\mathbf{c}$ the solvent was $\mathrm{D}_{2} \mathrm{O}$, but one or two drops of TFA had to be added to help solubilize $\mathbf{2 a}-\mathbf{c}$ and to avoid deuteration at $\mathrm{C}^{\prime}$ in the case of $\mathbf{3 c}$, with a glass capillary filled with $\mathrm{CHCl}_{3}$ inside, that is, with $\mathrm{CHCl}_{3}$ as external reference. ${ }^{13} \mathrm{C}$ NMR spectra were recorded in $\mathrm{CDCl}_{3}$, DMSO- $d_{6}$, or $\mathrm{D}_{2} \mathrm{O}$ at $100.6 \mathrm{MHz}$ with proton decoupling. Chemical shifts are reported in $\operatorname{ppm}\left(\mathrm{CDCl}_{3}, \delta 77.0 \mathrm{ppm}\right.$; DMSO- $\left.d_{6}, \delta 39.5 \mathrm{ppm}\right)$. For $\mathbf{2 a - c}$ and $\mathbf{3 a}-\mathbf{c}$ the solvent was $\mathrm{D}_{2} \mathrm{O}$, plus one or two drops of TFA in the cases of $\mathbf{2 a - c}$ and $\mathbf{3 c}$, with an internal capillary filled with $\mathrm{CDCl}_{3}$ [TFA in $\mathrm{CDCl}_{3}, \delta 116.5(\mathrm{q}, J=290.4 \mathrm{~Hz}), 164.4$ (q, $J=36.6 \mathrm{~Hz}$ ], as external reference. Where necessary, 2D NMR experiments (HSQC and NOESY, mainly) were carried out to assist in structure elucidation and signal assignments. FTIR spectra were registered with an ATR accessory; only the more relevant frequencies $\left(\mathrm{cm}^{-1}\right)$ are reported. HRMS were obtained by using ESI-TOF techniques.

General Procedure for the Addition of Thiols 1-3 to Propynamides (Propiolamides) a and b in Aqueous Media. Thiols 1-3 (in general, $0.20-0.50 \mathrm{mmol})$ were dissolved in phosphate-buffered solutions $(2.5 \mathrm{~mL})$ under $\mathrm{N}_{2}$; in the cases of $\mathbf{2}$ and $\mathbf{3}$, solid $\mathrm{K}_{2} \mathrm{HPO}_{4}$ was added until the $\mathrm{pH}$ value was 7.40 (pHmeter). These solutions were slowly added, over $10 \mathrm{~min}$, to the propynamides $(0.22-0.55 \mathrm{mmol})$ in $2.5 \mathrm{~mL}$ of $\mathrm{H}_{2} \mathrm{O},{ }^{\mathrm{t}} \mathrm{BuOH}, \mathrm{EtOH}, \mathrm{THF}$, or THF-buffered water, either at $\mathrm{rt}$ or $37^{\circ} \mathrm{C}$. The reactions were stirred until TLC analysis indicated complete consumption of the substrate (usually for further $10-60 \mathrm{~min}$, see Table 1 ). The conversion yields were $100 \%$ in all cases, at $\mathrm{pH} \geq 7.4$.

The reaction mixtures from 1 were diluted with $\mathrm{H}_{2} \mathrm{O}$ and extracted three times with $\mathrm{CH}_{2} \mathrm{Cl}_{2}$. The organic layers were collected, dried over anhydrous $\mathrm{MgSO}_{4}$, filtered, concentrated under vacuum, and analyzed by NMR (last column in Table 1). The residues were usually purified by column chromatography on silica gel (to remove small amounts of the $E$ isomers) and the solids were then stored in vacuum desiccators over $\mathrm{P}_{4} \mathrm{O}_{10}$ until constant weight (isolated yields, Table 1). The reaction mixtures from 2 were concentrated under vacuum (to remove ${ }^{t} \mathrm{BuOH}$ ) and the precipitates that appeared were filtered, rinsed with water, dried under vacuum over $\mathrm{P}_{4} \mathrm{O}_{10}$, weighted, and analyzed by TLC and NMR (yields and percentages given in Table 1). The crude products from most experiments were chromatographically and spectroscopically pure (only the $Z$ isomers of $\mathbf{2 a}$ and $\mathbf{2 b}$ ); no recrystallization was needed. The reaction mixtures from 3 were acidified to $\mathrm{pH} 3.5$ with $\mathrm{NaH}_{2} \mathrm{PO}_{4}\left(\mathrm{plus}\right.$ a drop of $\left.\mathrm{H}_{3} \mathrm{PO}_{4}\right)$ and a similar volume of EtOH was added and separated (three times), the moist EtOH solutions were evaporated to dryness, the residues were treated with 4:1 ${ }^{\mathrm{i}} \mathrm{PrOH}-\mathrm{H}_{2} \mathrm{O}$, the solutions were filtered through Celite ${ }^{\circledR}$ (to remove remaining amounts of the insoluble phosphates) and rinsed with the same mixture ( ${ }^{\mathrm{i}} \mathrm{PrOH}-\mathrm{H}_{2} \mathrm{O}$ ), evaporated to dryness, stored in the desiccator, weighted (yield in Table 1), and analyzed by NMR (last column in Table 1). In two experiments (in which a mixture of stereoisomers was formed), the crude products were recrystallized from ${ }^{\mathrm{i}} \mathrm{PrOH}-\mathrm{H}_{2} \mathrm{O}(80-85 \%$ recovery) to remove the minor $E$ isomers.

We proceeded similarly with the other commercially available Michael acceptors: $N$-(phenylmethyl)maleimide, or $N$-benzylmaleimide, c; $N$-benzyl-3-iodopropenamides $\mathbf{d}$ and $\mathbf{e}$; and $N$-benzylpropenamide $\mathbf{f}$.

Methyl N-acetyl-S-[(Z)-3-phenylmethylamino)-3-oxo-1-propen-1-yl]-L-cysteinate, (Z)-1a. Yield: 94\% (91 mg). White solid; mp 123-125 ${ }^{\circ} \mathrm{C} ; R_{f}=0.30$ $\left(\mathrm{CH}_{2} \mathrm{Cl}_{2} / \mathrm{MeOH}, 98: 2\right) .{ }^{1} \mathrm{H} \mathrm{NMR}\left(\mathrm{CDCl}_{3}\right) 2.01(\mathrm{~s}, 3 \mathrm{H}), 3.24(\mathrm{~d}, J=4.5,2 \mathrm{H}), 3.76(\mathrm{~s}, 3 \mathrm{H}), 4.47(\mathrm{~d}, J=5.8,2 \mathrm{H}), 4.85(\mathrm{~m}, 1 \mathrm{H}), 5.78(\mathrm{~d}, J=9.9,1 \mathrm{H}), 5.89(\mathrm{br}$ 
s, $1 \mathrm{H}), 6.43$ (br s, $1 \mathrm{H}), 6.76(\mathrm{~d}, J=9.9,1 \mathrm{H}), 7.29(\mathrm{~m}, 5 \mathrm{H}) .{ }^{13} \mathrm{C} \mathrm{NMR}\left(\mathrm{CDCl}_{3}\right)$ 23.2, 38.5, 43.6, 53.0, 53.0, 116.0, 127.7, 128.1, 128.8, 138.3, 145.2, 166.0, 170.1, 170.6. FTIR 3303, 3271, 3069, 2917, 1738, 1660, 1632. HRMS (ESI+) $m / z$ calcd for $\mathrm{C}_{16} \mathrm{H}_{21} \mathrm{~N}_{2} \mathrm{O}_{4} \mathrm{~S}^{+}[\mathrm{M}+\mathrm{H}]^{+} 337.1217$, found 337.1221.

Methyl N-acetyl-S-[(Z)-3-N-morpholino-3-oxo-1-propen-1-yl]-L-cysteinate, (Z)-1b. Yield: $98 \%$ (89 mg). White solid; mp $177-178{ }^{\circ} \mathrm{C} ; R_{f}=0.28$ $\left(\mathrm{CH}_{2} \mathrm{Cl}_{2} / \mathrm{MeOH}, 98: 2\right) .{ }^{1} \mathrm{H}$ NMR $\left(\mathrm{CDCl}_{3}\right) 2.03(\mathrm{~s}, 3 \mathrm{H}), 3.25(\mathrm{~d}, J=4.5,2 \mathrm{H}), 3.49(\mathrm{br} \mathrm{s}, 2 \mathrm{H}), 3.68(\mathrm{br} \mathrm{s}, 6 \mathrm{H}), 3.77(\mathrm{~s}, 3 \mathrm{H}), 4.88(\mathrm{~m}, 1 \mathrm{H}), 6.16(\mathrm{~d}, J=9.9$, 1H), 6.36 (br s, 1H), $6.90(\mathrm{~d}, J=9.9,1 \mathrm{H}) ;{ }^{13} \mathrm{C} \mathrm{NMR}\left(\mathrm{CDCl}_{3}, 100.6 \mathrm{MHz}\right) \delta 23.2,38.5,41.9,46.1,52.7,53.0,66.8,67.0,111.8,147.6,165.5,170.0$, 170.6. FTIR 3278, 3069, 2914, 2850, 1721, 1639, 1625, 1614. HRMS (ESI + ) $m / z$ calcd for $\mathrm{C}_{13} \mathrm{H}_{21} \mathrm{~N}_{2} \mathrm{O}_{5} \mathrm{~S}^{+}[\mathrm{M}+\mathrm{H}]^{+} 317.1166$, found 317.1171 .

S-I(Z)-3-Phenylmethylamino-3-oxo-1-propen-1-yl]-L-cysteine, (Z)-2a. Yield: $96 \%(56 \mathrm{mg})$. White solid; dec. $215-217{ }^{\circ} \mathrm{C} ; R_{f}=0.71\left(\mathrm{CH}_{2} \mathrm{Cl}_{2} /-\right.$ MeOH/TFA, 80:15:5). ${ }^{1} \mathrm{H}$ NMR $\left(\mathrm{D}_{2} \mathrm{O}+\mathrm{TFA}\right.$, ref. to $\left.\mathrm{CHCl}_{3}\right) 3.41(\mathrm{~m}, 3 \mathrm{H}), 4.40(\mathrm{~s}, 2 \mathrm{H}), 6.09(\mathrm{~d}, J=10.0,1 \mathrm{H}), 7.01(\mathrm{~d}, J=10.0,1 \mathrm{H}), 7.35(\mathrm{~m}, 5 \mathrm{H}) .{ }^{13} \mathrm{C}$ $\operatorname{NMR}\left(\mathrm{D}_{2} \mathrm{O}+\mathrm{TFA}\right.$, ref. to $\left.\mathrm{CDCl}_{3}\right) 35.5,43.0,53.0,117.4,127.5,129.0,129.4,138.3,143.6,170.0,170.4$. HRMS (ESI-) $m / z$ calcd for $\mathrm{C}_{13} \mathrm{H}_{15} \mathrm{~N}_{2} \mathrm{O}_{3} \mathrm{~S}^{-}[\mathrm{M}$ $-\mathrm{H}]^{-} 279.0809$, found 279.0815 .

S-I(Z)-3-Morpholino-3-oxo-1-propen-1-yl]-L-cysteine, (Z)-2b. Yield: 97\% (65 mg). White solid, dec. $198-200{ }^{\circ} \mathrm{C} ; R_{f}=0.62\left(\mathrm{CH}{ }_{2} \mathrm{Cl} / 2 \mathrm{MeOH} /-\right.$ TFA, 80:15:5). ${ }^{1} \mathrm{H}$ NMR $\left(\mathrm{D}_{2} \mathrm{O}+\mathrm{TFA}\right.$, ref. to $\left.\mathrm{CHCl}_{3}\right) 3.55(\mathrm{~m}, 3 \mathrm{H}), 3.83(\mathrm{~m}, 2 \mathrm{H}), 3.97(\mathrm{~m}, 6 \mathrm{H}), 6.66(\mathrm{~d}, J=10.1,1 \mathrm{H}), 7.37(\mathrm{~d}, J=10.1,1 \mathrm{H}) .{ }^{13} \mathrm{C}$ NMR $\left(\mathrm{D}_{2} \mathrm{O}+\right.$ TFA, ref. to $\left.\mathrm{CDCl}_{3}\right) 32.6,36.1,42.3,54.3,63.8,66.6,113.9,146.0,167.1,172.1$. HRMS $\left(\mathrm{ESI}^{-}\right) m / z$ calcd for $\mathrm{C}_{10} \mathrm{H}_{15} \mathrm{~N}_{2} \mathrm{O}_{4} \mathrm{~S}^{-}\left[\mathrm{M}-\mathrm{H}^{-}\right.$ 259.0758, found 259.0766.

S-I(Z)-3-Phenylmethylamino-3-oxo-1-propen-1-yllglutathione, (Z)-3a. Yield (entry 18): 93\% (152 mg). White solid; dec. $236-237^{\circ} \mathrm{C} ; R_{f}=0.55$ $\left(\mathrm{CH}_{2} \mathrm{Cl}_{2} / \mathrm{MeOH} / \mathrm{TFA}, 80: 15: 5\right) .{ }^{1} \mathrm{H} \mathrm{NMR}\left(\mathrm{D}_{2} \mathrm{O}\right) 2.13(\mathrm{~m}, 2 \mathrm{H}), 2.50(\mathrm{t}, J=7.1,2 \mathrm{H}), 3.08(\mathrm{dd}, J=13.8,9.8,1 \mathrm{H}), 3.29(\mathrm{~d}, J=13.9,1 \mathrm{H}), 3.75(\mathrm{~m}, 3 \mathrm{H})$, $4.40(\mathrm{~s}, 2 \mathrm{H}), 4.66(\mathrm{~m}, 1 \mathrm{H}), 6.03(\mathrm{~d}, J=10.0,1 \mathrm{H}), 7.03(\mathrm{~d}, J=10.0,1 \mathrm{H}), 7.40(\mathrm{~m}, 5 \mathrm{H}) .{ }^{13} \mathrm{C} \mathrm{NMR}\left(\mathrm{D}_{2} \mathrm{O}, \mathrm{ref}\right.$ to $\left.\mathrm{CDCl}_{3}\right) 26.4,31.7,37.1,43.0,43.6$, 54.0, 54.3, 116.3, 127.5, 127.6, 129.0, 138.5, 145.2, 168.6, 171.6, 174.1, 175.0, 176.4. HRMS (ESI+) $m / z$ calcd for $\mathrm{C}_{20} \mathrm{H}_{27} \mathrm{~N}_{4} \mathrm{O}_{7} \mathrm{~S}^{+}[\mathrm{M}+\mathrm{H}]^{+}$ 467.1595, found 467.1596; HRMS (ESI-) $\mathrm{m} / z$ calcd for $\mathrm{C}_{20} \mathrm{H}_{25} \mathrm{~N}_{4} \mathrm{O}_{7} \mathrm{~S}^{-}[\mathrm{M}-\mathrm{H}]^{-} 465.1449$, found 465.1463 .

S-I(Z)-3-N-Morpholino-3-oxo-1-propen-1-yllglutathione, (Z)-3b. Yield: 95\% (146 mg). White solid; dec. $220-222{ }^{\circ} \mathrm{C} ; R_{f}=0.55\left(\mathrm{CH}_{2} \mathrm{Cl}_{2} /-\right.$ MeOH/TFA, 80:15:5). ${ }^{1} \mathrm{H}$ NMR $\left(\mathrm{D}_{2} \mathrm{O}\right) 2.13(\mathrm{~m}, 2 \mathrm{H}), 2.49(\mathrm{~m}, 2 \mathrm{H}), 3.07(\mathrm{dd}, J=14.4,8.8,1 \mathrm{H}), 3.28(\mathrm{dd}, J=14.3,5.0,1 \mathrm{H}), 3.59(\mathrm{~m}, 4 \mathrm{H}), 3.71(\mathrm{~m}$, $7 \mathrm{H}), 4.63(\mathrm{dd}, J=8.8,5.0,1 \mathrm{H}), 6.36(\mathrm{~d}, J=10.1,1 \mathrm{H}), 7.13(\mathrm{~d}, J=10.2,1 \mathrm{H}) .{ }^{13} \mathrm{C} \mathrm{NMR}\left(\mathrm{D}_{2} \mathrm{O}\right.$, ref. to $\left.\mathrm{CDCl}_{3}\right) 26.3,31.5,36.8,42.0,43.5,46.1,53.8$, 54.1, 66.4, 112.9, 147.0, 167.0, 171.4, 174.0, 174.8, 176.2. HRMS (ESI+) $m / z$ calcd for $\mathrm{C}_{17} \mathrm{H}_{27} \mathrm{~N}_{4} \mathrm{O}_{8} \mathrm{~S}^{+}[\mathrm{M}+\mathrm{H}]^{+}$447.1544, found 447.1545. HRMS (ESI-) $m / z$ calcd for $\mathrm{C}_{17} \mathrm{H}_{25} \mathrm{~N}_{4} \mathrm{O}_{8} \mathrm{~S}^{-}[\mathrm{M}-\mathrm{H}]^{-} 445.1399$, found 445.1413 .

Methyl N-acetyl-S-[(3RS)-1-phenylmethyl-2,5-dioxopyrrolidin-3-yl]-L-cysteinate, 1c. Yield: 98\% (61 mg); ca. 1:1 diastereomeric mixture. Yellowish oil; $R_{f}=0.34$ (hexanes/EtOAc, 20:80). ${ }^{1} \mathrm{H}$ NMR $\left(\mathrm{CDCl}_{3}\right) 2.02(\mathrm{~s}, 3 \mathrm{H}), 2.04(\mathrm{~s}, 3 \mathrm{H}), 2.46(\mathrm{dd}, J=18.8,3.9,1 \mathrm{H}), 2.50(\mathrm{dd}, J=18.8,4.1$, 1H), $2.99(\mathrm{dd}, J=14.0,7.5,1 \mathrm{H}), 3.14(\mathrm{~m}, 3 \mathrm{H}), 3.45(\mathrm{dd}, J=14.4,5.2,1 \mathrm{H}), 3.49(\mathrm{dd}, J=14.0,4.4,1 \mathrm{H}), 3.75(\mathrm{dd}, J=9.2,4.1,1 \mathrm{H}), 3.76(\mathrm{~s}, 6 \mathrm{H}), 3.91$ $(\mathrm{dd}, J=9.2,3.9,1 \mathrm{H}), 4.66(\mathrm{~m}, 4 \mathrm{H}), 4.89(\mathrm{~m}, 2 \mathrm{H}), 6.43$ (br s, $1 \mathrm{H}), 6.90($ br s, $1 \mathrm{H}), 7.32(\mathrm{~m}, 10 \mathrm{H}) .{ }^{13} \mathrm{C} \mathrm{NMR}\left(\mathrm{CDCl}_{3}\right) 23.2,23.2,34.3,35.0,35.8,36.5$, $38.9,40.4,42.8,42.9,51.4,52.4,52.9,53.0,128.2,128.3,128.7,128.8,128.9,128.9,135.3,135.4,170.2,170.3,171.0,171.2,173.8,174.1,176.6$ 176.8. FTIR 3303, 2960, 1741, 1697, 1670, 1626. HRMS (ESI+) $m / z$ calcd for $\mathrm{C}_{17} \mathrm{H}_{21} \mathrm{~N}_{2} \mathrm{O}_{5} \mathrm{~S}^{+}[\mathrm{M}+\mathrm{H}]^{+} 365.1166$, found 365.1171.

S-[(3RS)-1-Phenylmethyl-2,5-dioxopyrrolidin-3-yl]-L-cysteine, 2c. Yield: 94\% (80 mg); nearly 1:1 diastereomeric mixture. White solid, $R_{f}=$ $0.63\left(\mathrm{CH}_{2} \mathrm{Cl}_{2} / \mathrm{MeOH} / \mathrm{TFA}, 80: 15: 5\right),{ }^{1} \mathrm{H}$ NMR $\left(\mathrm{D}_{2} \mathrm{O}+\mathrm{TFA}\right.$, ref. to $\left.\mathrm{CHCl}_{3}\right) 2.69$ (br d, $\left.J=18.8,1 \mathrm{H}\right), 2.70($ br d, $J=18.8,1 \mathrm{H}), 3.17(\mathrm{dd}, J=15.0,8.1$, $1 \mathrm{H}), 3.31(\mathrm{~m}, 3 \mathrm{H}), 3.43(\mathrm{dd}, J=15.2,4.4,1 \mathrm{H}), 3.49(\mathrm{dd}, J=15.0,4.4,1 \mathrm{H}), 4.05(\mathrm{dd}, J=9.8,4.2,1 \mathrm{H}), 4.08(\mathrm{dd}, J=9.8,4.0,1 \mathrm{H}), 4.27(\mathrm{dd}, J=8.1$, 
$4.5,1 \mathrm{H}), 4.41(\mathrm{dd}, J=7.6,4.5,1 \mathrm{H}), 4.66(\mathrm{~m}, 4 \mathrm{H}), 7.32(\mathrm{~m}, 10 \mathrm{H}) .{ }^{13} \mathrm{C} \mathrm{NMR}\left(\mathrm{D}_{2} \mathrm{O}+\mathrm{TFA}\right.$, ref. to $\left.\mathrm{CDCl}_{3}\right) 31.0,32.3,35.6,36.0,40.0,41.3,42.7,42.8$ 52.3, 53.0, 128.0, 128.0, 128.4, 129.1, 129.1, 135.2, 162.5, 162.9, 170.0, 170.1, 177.6, 178.9, 179.5. HRMS (ESI-) $m / z$ calcd for $\mathrm{C}_{14} \mathrm{H}_{15} \mathrm{~N}_{2} \mathrm{O}_{4} \mathrm{~S}^{-}[\mathrm{M}-$ $\mathrm{H}]^{-}$307.0758, found 307.0763 .

S-[(3RS)-1-Phenylmethyl-2,5-dioxopyrrolidin-3-yl]glutathione, $3 c .{ }^{19}$ Yield: $92 \%(161 \mathrm{mg})$; almost 1:1 diastereomeric mixture. White solid; $R_{f}=$ $0.54\left(\mathrm{CH}_{2} \mathrm{Cl}_{2} / \mathrm{MeOH} / \mathrm{TFA}, 80: 15: 5\right) .{ }^{1} \mathrm{H} \mathrm{NMR}\left(\mathrm{D}_{2} \mathrm{O}+\mathrm{TFA}\right.$, ref. to $\left.\mathrm{CHCl}_{3}\right) 2.20(\mathrm{~m}, 4 \mathrm{H}), 2.54(\mathrm{~m}, 4 \mathrm{H}), 2.63(\mathrm{dd}, J=9.9,3.8,1 \mathrm{H}), 2.68(\mathrm{dd}, J=$ 9.9, 3.9, 1H), $2.94(\mathrm{dd}, J=14.0,8.6,1 \mathrm{H}), 3.10(\mathrm{dd}, J=14.0,7.8,1 \mathrm{H}), 3.11(\mathrm{dd}, J=14.0,5.6,1 \mathrm{H}), 3.27(\mathrm{dd}, J=19.0,6.6,1 \mathrm{H}), 3.28(\mathrm{dd}, J=$ $19.0,6.5,1 \mathrm{H}), 3.95(\mathrm{~s}, 2 \mathrm{H}), 3.97(\mathrm{~s}, 2 \mathrm{H}), 4.01(\mathrm{dd}, J=9.0,3.9,1 \mathrm{H}), 4.03(\mathrm{dd}, J=8.9,3.7,1 \mathrm{H}), 4.06(\mathrm{dd}, J=5.0,1.7,1 \mathrm{H}), 4.07(\mathrm{dd}, J=6.5$, $3.3,1 \mathrm{H}), 4.59(\mathrm{~d}, J=5.6,1 \mathrm{H}), 4.61(\mathrm{~d}, J=5.3,1 \mathrm{H}), 4.63(\mathrm{~s}, 4 \mathrm{H}), 7.30(\mathrm{~m}, 10 \mathrm{H}) .{ }^{13} \mathrm{C} \mathrm{NMR}\left(\mathrm{D}_{2} \mathrm{O}+\mathrm{TFA}, \mathrm{ref}\right.$ to $\left.\mathrm{CDCl}_{3}\right) 25.4,25.4,30.9,32.5$, $32.7,35.8,36.0,39.9,40.6,41.1,42.4,52.2,52.6,53.1,127.7,128.1,128.9,135.1,171.4,172.2,172.3,172.8,172.8,174.2,174.2,177.8$, $177.8,179.0,179.1$

Methyl N-acetyl-S-[(E)-3-phenylmethylamino)-3-oxo-1-propen-1-yl]-L-cysteinate, 1e [(E)-1a]. Yield: $95 \%(70 \mathrm{mg})$. White solid; $\mathrm{mp} 105-107^{\circ} \mathrm{C} ; R_{f}=$ $0.30\left(\mathrm{CH}_{2} \mathrm{Cl}_{2} / \mathrm{MeOH}, 98: 2\right) .{ }^{1} \mathrm{H} \mathrm{NMR}\left(\mathrm{CDCl}_{3}\right) 2.00(\mathrm{~s}, 3 \mathrm{H}), 3.23(\mathrm{dd}, J=14.1,4.8,1 \mathrm{H}), 3.32(\mathrm{dd}, J=14.1,5.0,1 \mathrm{H}), 3.77(\mathrm{~s}, 3 \mathrm{H}), 4.46(\mathrm{~d}, J=5.6$, $2 \mathrm{H}), 4.88(\mathrm{dt}, J=7.3,4.9,1 \mathrm{H}), 5.92(\mathrm{~d}, J=14.9,1 \mathrm{H}), 6.15(\mathrm{br} \mathrm{s}, 1 \mathrm{H}), 6.57(\mathrm{br} \mathrm{d}, J=7.3,1 \mathrm{H}), 7.27(\mathrm{~m}, 5 \mathrm{H}), 7.50(\mathrm{~d}, J=14.9,1 \mathrm{H}) .{ }^{13} \mathrm{C} \mathrm{NMR}$ $\left(\mathrm{CDCl}_{3}\right)$ 23.0, 34.6, 43.7, 52.0, 53.0, 117.7, 127.5, 127.8, 128.7, 138.1, 141.8, 164.1, 170.2, 170.4. HRMS $\left(\mathrm{ESI}^{+}\right) m / z$ calcd for $\mathrm{C}_{16} \mathrm{H}_{21} \mathrm{~N}_{2} \mathrm{O}_{4} \mathrm{~S}^{+}\left[\mathrm{M}+\mathrm{H}^{+}\right.$ 337.1215 , found 337.1221 .

Methyl N-acetyl-S-(3-phenylmethylamino-3-oxopropyl)-L-cysteinate, 1f. Yield: 91\% (99 mg). Oil; $R_{f}=0.66\left(\mathrm{CH}_{2} \mathrm{Cl}{ }_{2} / \mathrm{MeOH}, 99: 1\right) .{ }^{1} \mathrm{H} \mathrm{NMR}$ $\left(\mathrm{CDCl}_{3}\right) 1.99(\mathrm{~s}, 3 \mathrm{H}), 2.48(\mathrm{~m}, 2 \mathrm{H}), 2.86(\mathrm{t}, J=7.0,2 \mathrm{H}), 2.96(\mathrm{~d}, J=5.1,2 \mathrm{H}), 3.73(\mathrm{~s}, 3 \mathrm{H}), 4.43(\mathrm{~d}, J=5.7,2 \mathrm{H}), 4.80(\mathrm{~m}, 1 \mathrm{H}), 6.35(\mathrm{br} \mathrm{s}, 1 \mathrm{H}), 6.72$ (br s, 1H), 7.28 (m, 5H). ${ }^{13} \mathrm{C} \mathrm{NMR}\left(\mathrm{CDCl}_{3}\right)$ 23.0, 28.6, 34.5, 36.5, 43.7, 52.3, 52.7, 127.5, 127.8, 128.7, 138.1, 170.3, 170.8, 171.2. FTIR 3275, 3033, 1744, 1639. HRMS (ESI+) $m / z$ calcd for $\mathrm{C}_{16} \mathrm{H}_{23} \mathrm{~N}_{2} \mathrm{O}_{4} \mathrm{~S}^{+}[\mathrm{M}+\mathrm{H}]^{+} 339.1373$, found 339.1379.

Propynamide g. Yield: 43\% (330 mg). Colorless oil; $R_{f}=0.47\left(\mathrm{CH}_{2} \mathrm{Cl}_{2} / \mathrm{MeOH}, 95: 5\right)$. Mixture of rotamers (piperazine ring): ${ }^{1} \mathrm{H} \mathrm{NMR}$ $\left(\mathrm{CDCl}_{3}\right) 1.25($ br s, 3H), $1.75(\mathrm{~m}, 2 \mathrm{H}), 2.83(\mathrm{~s}, 1 \mathrm{H}), 3.39(\mathrm{~s}, 2 \mathrm{H}), 3.49(\mathrm{~s}, 2 \mathrm{H}), 4.80-3.11(\mathrm{~m}, 7 \mathrm{H}), 6.97(\mathrm{br} \mathrm{s}, 1 \mathrm{H}), 7.28(\mathrm{~m}, 1 \mathrm{H}), 7.39(\mathrm{~m}, 5 \mathrm{H})$, $7.63(\mathrm{~d}, J=7.4,1 \mathrm{H}), 7.69$ (br s, $1 \mathrm{H}), 8.01(\mathrm{~s}, 1 \mathrm{H}), 8.42$ (br s, $1 \mathrm{H}), 11.42$ (br s, $1 \mathrm{H}) .{ }^{13} \mathrm{C} \mathrm{NMR}\left(\mathrm{CDCl}_{3}\right)$ 15.3, 29.5, 36.0, 37.0, 40.1, 45.0, 50.1, 74.1, 77.4, 114.3, 116.9, 121.8, 122.9, 126.1, 127.0, 127.1, 128.8, 130.2, 135.1, 135.2, 136.4, 153.3, 166.2, 167.5, 171.5, 185.6. HRMS (ESI+) $m / z$ calcd for $\mathrm{C}_{29} \mathrm{H}_{30} \mathrm{~N}_{5} \mathrm{O}_{5}^{+}[\mathrm{M}+\mathrm{H}]^{+}$528.2241, found 528.2242.

Adduct of methyl N-acetyl-L-cysteinate and propanamide g (1g). Yield: 98\% (80 mg). Yellowish oil; $R_{f}=0.19\left(\mathrm{CH}_{2} \mathrm{Cl}{ }_{2} / \mathrm{MeOH}, 95: 5\right)$. Mixture of rotamers: ${ }^{1} \mathrm{H}$ NMR $\left(\mathrm{CDCl}_{3}\right) 1.28(\mathrm{br} \mathrm{s}, 3 \mathrm{H}), 1.73(\mathrm{~m}, 2 \mathrm{H}), 2.04(\mathrm{~s}, 3 \mathrm{H}), 2.98-3.47(\mathrm{~m}, 12 \mathrm{H}), 3.77(\mathrm{~s}, 4 \mathrm{H}), 4.84(\mathrm{br} \mathrm{s}, 1 \mathrm{H}), 5.79(\mathrm{~d}, \mathrm{~J}$ $=9.9,1 \mathrm{H}), 6.48(\mathrm{br} \mathrm{s}, 1 \mathrm{H}), 6.72(\mathrm{~d}, J=9.7,1 \mathrm{H}), 7.29(\mathrm{~m}, 1 \mathrm{H}), 7.39(\mathrm{~m}, 5 \mathrm{H}), 7.64(\mathrm{~d}, J=7.3,1 \mathrm{H}), 7.73(\mathrm{~d}, J=6.9,1 \mathrm{H}), 7.92(\mathrm{br} \mathrm{s}, 1 \mathrm{H}), 8.02$ (m, 1H), 8.42 (br s, $1 \mathrm{H}), 11.33$ (s, 1H). ${ }^{13} \mathrm{C}$ NMR $\left(\mathrm{CDCl}_{3}\right)$ 15.2, 16.4, 23.3, 29.4, 29.8, 36.3, 36.4, 36.7, 38.4, 45.0, 52.7, 52.9, 114.2, 116.4, $117.4,122.2,122.9,125.9,126.7,127.1,128.8,130.2,135.1,136.2,136.6,144.7,167.2,167.4,167.5,170.4,170.5,170.8,185.6$. HRMS (ESI+) $m / z$ calcd for $\mathrm{C}_{35} \mathrm{H}_{41} \mathrm{~N}_{6} \mathrm{O}_{8} \mathrm{~S}^{+}[\mathrm{M}+\mathrm{H}]^{+}$705.2701, found 705.2699.

Adduct of L-cysteine and propanamide $\mathbf{g}$ (2g). Yield: 97\% (103 mg). Yellowish oil; $R_{f}=0.33\left(\mathrm{CH}_{2} \mathrm{Cl}_{2} / \mathrm{MeOH} / \mathrm{TFA}, 80: 15: 5\right)$. Mixture of rotamers: ${ }^{1} \mathrm{H}$ NMR (DMSO- $\left.d_{6}\right) 1.21(\mathrm{br} \mathrm{s}, 3 \mathrm{H}), 1.72$ (quin, $\left.J=6.9,2 \mathrm{H}\right), 2.71-4.60(\mathrm{~m}, 13 \mathrm{H}), 4.22(\mathrm{~s}, 1 \mathrm{H}), 5.95(\mathrm{~d}, J=9.8,1 \mathrm{H}), 6.90(\mathrm{~d}, J=$ $10.0,1 \mathrm{H}), 7.40(\mathrm{~m}, 6 \mathrm{H}), 7.82(\mathrm{~d}, J=7.6,1 \mathrm{H}), 8.05(\mathrm{~d}, J=3.3,1 \mathrm{H}), 8.29(\mathrm{br} \mathrm{s}, 1 \mathrm{H}), 8.75(\mathrm{t}, J=5.6,1 \mathrm{H}), 12.20(\mathrm{~d}, J=12.9,1 \mathrm{H}) .{ }^{13} \mathrm{C} \mathrm{NMR}$ 
$\left(\mathrm{DMSO}_{6}\right) 14.9,16.0,28.8,29.3,32.2,36.8,36.9,37.0,37.4,44.3,51.4,112.7,117.9,118.5,122.3,122.4,124.4,126.3,127.1,128.6,129.8$, 135.2, 135.6, 138.0, 142.3, 165.8, 165.9, 166.1, 169.4, 186.0. HRMS (ESI $\left.{ }^{-}\right) m / z$ calcd for $\mathrm{C}_{32} \mathrm{H}_{35} \mathrm{~N}_{6} \mathrm{O}_{7} \mathrm{~S}^{-}[\mathrm{M}-\mathrm{H}]^{-}$647.2293, found 647.2296.

\section{ASSOCIATED CONTENT}

\section{Supporting Information}

The Supporting Information is available free of charge on the ACS Publications website at DOI: 10.1021/acs.joc........

${ }^{1} \mathrm{H}$ NMR and ${ }^{13} \mathrm{C}$ NMR spectra of the new compounds and 2D NMR spectra of 1c

\section{AUTHOR INFORMATION}

\section{Corresponding Authors}

*E-mail: amcosta@ub.edu (A.M.C.). ORCID

*E-mail: jvilarrasa@ub.edu (J.V.).

ORCID

Anna M. Costa: 0000-0003-4345-4750

Jaume Vilarrasa: 0000-0002-2522-8218

Notes

The authors declare no competing financial interest.

\section{ACKNOWLEDGMENTS}

Grant CTQ2015-71506-R (Spanish Government, FEDER) is acknowledged. E.P. was a fellow of the Fundació Cellex of Barcelona during 2017 and the first half of 2018. Preliminary experiments, mainly with alkyl propynoates and/or under non-physiological conditions, of Anna Ruiz-Mitjana during her Master in Biotechnology (first half of 2017), of the undergraduate student Laura Díaz-Atienza (TFG, 2017), and of Itzel A. Bernal (Maestría, UA Estado de Mexico, Conacyt, October 2017-March 2018) deserve to be mentioned. This work is dedicated to the late President of the Fundació Cellex of Barcelona, chemist and entrepreneur, Dr. Pere Mir (deceased 10 March 2017).

\section{REFERENCES}

(1) For very recent reviews, see: (a) Tsuchikama, K.; An, Z. Antibody-Drug Conjugates: Recent Advances in Conjugation and Linker Chemistries. Protein Cell 2018, 9, 33-46. (b) Rodrigues, T.; Bernardes, G. J. L. Development of Antibody-Directed Therapies: Quo Vadis? Angew. Chem., Int. Ed. 2018, 57, 2032-2034. (c) Lambert, J. M.; Berkenblit, A. Antibody-Drug Conjugates for Cancer Treatment. Annu. Rev. Med. 2018, 69, 191-207. (d) Beck, A.; Goetsch, L.; Dumontet, C.; Corvaïa, N. Strategies and Challenges for the Next Generation of AntibodyDrug Conjugates. Nat. Rev. Drug Discov. 2017, 16, 315-337. (e) Chudasama, V.; Maruani, A.; Caddick, S. Recent Advances in the Construction of Antibody-Drug Conjugates. Nat. Chem. 2016, 8, 114-119. 
(2) For reviews, see: (a) Sletten, E. M.; Bertozzi, C. R. Bioorthogonal Chemistry: Fishing for Selectivity in a Sea of Functionality. Angew. Chem., Int. Ed. 2009, 48, 6974-6998. (b) Kalia, J.; Raines, R. T. Advances in Bioconjugation. Curr. Org. Chem. 2010, 14, 138-147. (c) Yousuke, T.; Akio, O.; Itaru, H. Protein Organic Chemistry and Applications for Labeling and Engineering in Live-Cell Systems. Angew. Chem., Int. Ed. 2013, 52, 4088-4106. (d) Tang, W.; Becker, M. L. "Click” Reactions: A Versatile Toolbox for the Synthesis of PeptideConjugates. Chem. Soc. Rev. 2014, 43, 7013-7039. (e) Krall, N.; Cruz, F. P.; Boutureira, O.; Bernardes, G. J. L. Site-Selective ProteinModification Chemistry for Basic Biology and Drug Development. Nat. Chem. 2015, 8, 103-113.

(3) For reviews, see: (a) Chalker, J. M.; Bernardes, G. J.; Lin, Y. A.; Davis, B. G. Chemical Modification of Proteins at Cysteine: Opportunities in Chemistry and Biology. Chem. Asian J. 2009, 4, 630-640. (b) Jain, N.; Smith, S. W.; Ghone, S.; Tomczuk, B. Current ADC Linker Chemistry. Pharm. Res. 2015, 32, 3526-3540. (c) Jackson, D. Y. Processes for Constructing Homogeneous Antibody Drug Conjugates. Org. Proc. Res. Dev. 2016, 20, 852-866.

(4) (a) Baldwin, A. D.; Kiick, K. L. Tunable Degradation of Maleimide-Thiol Adducts in Reducing Environments. Bioconjug. Chem. 2011, 22, 1946-1953. (b) Shen, B.-Q.; Xu, K.; Liu, L.; Raab, H.; Bhakta, S.; Kenrick, M.; Parsons-Reponte, K. L.; Tien, J.; Yu, S.-F.; Mai, E.; Li, D.; Tibbits, J.; Baudys, J.; Saad, O. M.; Scales, S. J.; McDonald, P. J.; Hass, P. E.; Eigenbrot, C.; Nguyen, T.; Solis, W. A.; Fuji, R. N.; Flagella, K. M.; Patel, D.; Spencer, S. D.; Khawli, L. A.; Ebens, A.; Wong, W. L.; Vandlen, R.; Kaur, S.; Sliwkowski, M. X.; Scheller, R. H.; Polakis, P.; Junutula, J. R. Conjugation Site Modulates the in Vivo Stability and Therapeutic Activity of Antibody-Drug Conjugates. Nat. Biotechnol. 2012, 30, 184-189. (c) Ponte, J. F.; Sun, X.; Yoder, N. C.; Fishkin, N.; Laleau, R.; Coccia, J.; Lanieri, L.; Bogalhas, M.; Wang, L.; Wilhelm, S.; Widdison, W.; Pinkas, J.; Keating, T. A.; Chari, R.; Erickson, H. K.; Lambert, J. M. Understanding How the Stability of the Thiol-Maleimide Linkage Impacts the Pharmacokinetics of Lysine-Linked Antibody-Maytansinoid Conjugates. Bioconjug. Chem. 2016, 27, 1588-1598, and references therein. Also see: (d) Raycroft, M. A. R.; Racine, K. É.; Rowley, C. N.; Keillor, J. W. Mechanisms of Alkyl and Aryl Thiol Addition to N-Methylmaleimide. J. Org. Chem. 2018, 83, 11674-11685, and references therein.

(5) Several ingenious alternatives (dibromomaleimides, in situ transformations of the adducts, etc.) have been developed to overcome the maleimide drawbacks — retro-Michael/thiol exchange, partial hydrolysis, etc. - and to improve the homogeneity of drug-antibody ratios and sitespecific loading: (a) Robin, M. P.; Wilson, P.; Mabire, A. B.; Kiviaho, J. K.; Raymond, J. E.; Haddleton, D. M.; O'Reilly, R. K. ConjugationInduced Fluorescent Labeling of Proteins and Polymers Using Dithiomaleimides. J. Am. Chem. Soc. 2013, 135, 2875-2878. (b) Castaneda, L.; Maruani, A.; Schumacher, F. F.; Miranda, E.; Chudasama, V.; Chester, K. A.; Baker, J. R.; Smith, M. E. B.; Caddick, S. Acid-Cleavable Thiomaleamic Acid Linker for Homogeneous Antibody-Drug Conjugation. Chem. Comm. 2013, 49, 8187-8189. (c) Lyon, R. P.; Setter, J. R.; Bovee, T. D.; Doronina, S. O.; Hunter, J. H.; Anderson, M. E.; Balasubramanian, C. L.; Duniho, S. M.; Leiske, C. I.; Li, F.; Senter, P. D. SelfHydrolyzing Maleimides Improve the Stability and Pharmacological Properties of Antibody-Drug Conjugates. Nat. Biotechnol. 2014, 32, 10591065. (d) Tumey, L. N.; Charati, M.; He, T.; Sousa, E.; Ma, D.; Han, X.; Clark, T.; Casavant, J.; Loganzo, F.; Barletta, F.; Lucas, J.; Graziani, E. I. Mild Method for Succinimide Hydrolysis on ADCs: Impact on ADC Potency, Stability, Exposure, and Efficacy. Bioconjug. Chem. 2014, 25, 1871-1880. (e) Fontaine, S. D.; Reid, R.; Robinson, L.; Ashley, G. W.; Santi, D. V. Long-Term Stabilization of Maleimide-Thiol Conjugates. 
Bioconjug. Chem. 2015, 26, 145-152. (f) Nunes, J. P. M.; Morais, M.; Vassileva, V.; Robinson, E.; Rajkumar, V. S.; Smith, M. E. B.; Pedley, R. B.; Caddick, S.; Baker, J. R.; Chudasama, V. Functional Native Disulfide Bridging Enables Delivery of a Potent, Stable and Targeted AntibodyDrug Conjugate (ADC). Chem. Comm. 2015, 51, 10624-10627. (g) Kalia, D.; Malekar, P. V.; Parthasarathy, M. Exocyclic Olefinic Maleimides: Synthesis and Application for Stable and Thiol-Selective Bioconjugation. Angew. Chem., Int. Ed. 2016, 55, 1432-1435. (h) Kalia, D.; Pawar, S. P.; Topate, J. S. Stable and Rapid Thiol Bioconjugation by Light-Triggered Thiomaleimide Ring Hydrolysis. Angew. Chem., Int. Ed. 2017, 56, 1885-1889. (i) Chen, Z.; Boyd, S. D.; Calvo, J. S.; Murray, K. W.; Mejia, G. L.; Benjamin, C. E.; Welch, R. P.; Winkler, D. D.; Meloni, G.; D'Arcy, S.; Gassensmith, J. J. Fluorescent Functionalization across Quaternary Structure in a Virus-Like Particle. Bioconjug. Chem. 2017, 28, 2277-2283. (j) Morais, M.; Nunes, J. P. M.; Karu, K.; Forte, N.; Benni, I.; Smith, M. E. B.; Caddick, S.; Chudasama, V.; Baker, J. R. Optimisation of the Dibromomaleimide (DBM) Platform for Native Antibody Conjugation by Accelerated Post-Conjugation Hydrolysis. Org. Biomol. Chem. 2017, 15, 2947-2952. (k) Levengood, M. R.; Zhang, X.; Hunter, J. H.; Emmerton, K. K.; Miyamoto, J. B.; Lewis, T. S.; Senter, P. D. Orthogonal Cysteine Protection Enables Homogeneous Multi-Drug Antibody-Drug Conjugates. Angew. Chem., Int. Ed. 2017, 56, 733737, and references therein.

(6) (a) Truong, V. X.; Dove, A. P. Organocatalytic, Regioselective Nucleophilic "Click" Addition of Thiols to Propiolic Acid Esters for Polymer-Polymer Coupling. Angew. Chem., Int. Ed. 2013, 52, 4132-4136. (b) Badescu, G.; Bryant, P.; Swierkosz, J.; Khayrzad, F.; Pawlisz, E.; Farys, M.; Cong, Y.; Muroni, M.; Rumpf, N.; Brocchini, S.; Godwin, A. A New Reagent for Stable Thiol-Specific Conjugation. Bioconjug. Chem. 2014, 25, 460-469. (c) Nair, D. P.; Podgórski, M.; Chatani, S.; Gong, T.; Xi, W.; Fenoli, C. R.; Bowman, C. N. The Thiol-Michael Addition Click Reaction: A Powerful and Widely Used Tool in Materials Chemistry. Chem. Mater. 2014, 26, 724-744. (d) McKay, C. S.; Finn, M. G. Click Chemistry in Complex Mixtures: Bioorthogonal Bioconjugation. Chem. Biol. 2014, 21, 1075-1101. (e) Li, X.; Li, H.; Zhuang, J.; Li, H.; Wang, W. A Mild and Selective Protecting and Reversed Modification of Thiols. Tetrahedron Lett. 2016, 57, $2660-2663$. (f) Liu, Y.; Lai, Z.; Yang, P.; Xu, Y.; Zhang, W.; Liu, B.; Lu, M.; Chang, H.; Ding, T.; Xu, H. Thio-Michael Addition of $\alpha, \beta$-Unsaturated Amides Catalyzed by Nmm-Based Ionic Liquids. RSC Adv. 2017, 7, 43104 43113. (g) Sun, Y.; Zeng, X.; Xiao, Y.; Liu, C.; Zhu, H.; Zhou, H.; Chen, Z.; Xu, F.; Wang, J.; Zhu, M.; Wu, J.; Tian, M.; Zhang, H.; Deng, Z.; Cheng, Z.; Hong, X. Novel Dual-Function Near-Infrared II Fluorescence and PET Probe for Tumor Delineation and Image-Guided Surgery. Chem. Sci. 2018, 9, 2092-2097. And references cited therein.

(7) (a) Crisp, G. T.; Millan, M. J. Conjugate Addition of Amino Acid Side Chains to Alkynones and Alkynoic Acid Derivatives. Tetrahedron 1998, 54, 637-648. (b) Owen, T. C. Thiol Detection, Derivatization and Tagging at Micromole to Nanomole Levels Using Propiolates. Bioorg. Chem. 2008, 36, 156-160. (c) Arcadi, A.; Alfonsi, M.; Marinelli, F. Facile Reaction of Thiols and Amines with Alkyl 4Hydroxy-2-Alkynoates in Water under Neutral Conditions and Ultrasound Irradiation. Tetrahedron Lett. 2009, 50, 2060-2064. (d) Trofimov, B. A.; Mal'kina, A. G.; Shemyakina, O. A.; Nosyreva, V. V.; Borisova, A. P.; Khutsishvili, S. S.; Krivdin, L. B. Synthesis of Functionalized LCysteine and L-Methionine by Reaction with Electron-Deficient Acetylenes. Synthesis 2009, 3136-3142. (e) Shiu, H.-Y.; Chan, T.-C.; Ho, C.M.; Liu, Y.; Wong, M.-K.; Che, C.-M. Electron-Deficient Alkynes as Cleavable Reagents for the Modification of Cysteine-Containing Peptides in Aqueous Medium. Chem. Eur. J. 2009, 15, 3839-3850. (f) Randive, N. A.; Kumar, V.; Nair, V. A. A. Facile Approach to 
1

2

3

4

5

6

7

8

9

Substituted Acrylates by Regioselective and Stereoselective Addition of Thiols and Amines to an Alkynyl Ester in Water. Monatsh. Chem. 2010, 141, 1329-1332. (g) Koniev, O.; Leriche, G.; Nothisen, M.; Remy, J.-S.; Strub, J.-M.; Schaeffer-Reiss, C.; Van Dorsselaer, A.; Baati, R.; Wagner, R. A. Selective Irreversible Chemical Tagging of Cysteine with 3-Arylpropiolonitriles. Bioconjug. Chem. 2014, 25, 202-206.

(8) (a) Faja, M.; Ariza, X.; Gálvez, C.; Vilarrasa, J. Reaction of Uridines and Thymidines with Methyl Propynoate. A New N-3 Protecting Group. Tetrahedron Lett. 1995, 36, 3261-3264. (b) Ariza, X.; Costa, A. M.; Faja, M.; Pineda, O.; Vilarrasa, J. New Protecting Groups for 1,2Diols (Boc- and Moc-ethylidene). Cleavage of Acetals with Bases. Org. Lett. 2000, 2, 2809-2811. (c) Ariza, X.; Pineda, O.; Vilarrasa, J.; Shipps, G. W.; Ma, Y.; Dai, X. Bocdene and Mocdene Derivatives of Catechols and Catecholamines. Org. Lett. 2001, 3, 1399-1401. (d) Arjona, O.; Medel, R.; Rojas, J.; Costa, A. M.; Vilarrasa, J. Chemoselective Protection of Thiols versus Alcohols and Phenols. The Tosvinyl Group. Tetrahedron Lett. 2003, 44, 6369-6373. (e) Mola, L.; Font, J.; Bosch, L.; Caner, J.; Costa, A. M.; Etxebarría-Jardí, G.; Pineda, O.; Vicente, D.; Vilarrasa, J. Nucleophile-Catalyzed Additions to Activated Triple Bonds. Protection of Lactams, Imides, and Nucleosides with MocVinyl and Related Groups. J. Org. Chem. 2013, 78, 5832-5842. (f) Petit, E.; Bosch, L.; Font, J.; Mola, L.; Costa, A. M.; Vilarrasa, J. Tosvinyl and Besvinyl as Protecting Groups of Imides, Azinones, Nucleosides, Sultams, and Lactams. Catalytic Conjugate Additions to Tosylacetylene. J. Org. Chem. 2014, 79, 8826-8834.

(9) (a) Arjona, O.; Iradier, F.; Medel, R.; Plumet, J. p-Toluenesulfonylacetylene as Thiol Protecting Group. J. Org. Chem. 1999, 64, 60906093; also see Ref. 8d. (b) Medel, R.; Monterde, M. I., Plumet, J.; Rojas, J. K. Total Stereochemical Control in the Addition of Thiols to pToluenesulfonylacetylene. Synthesis of Z- and E-2-Sulfanylvinylsulfonyl Derivatives. J. Org. Chem. 2005, 70, 735-738. (c) Medel, R.; Plumet, J. Addition of Thiols to Sulfonylacetylenes: Synthetic Applications. Synthesis 2006, 1339-1342.

(10) (a) Coppola, G. M.; Damon, R. E. Acetylenic Amides. 1. Synthesis of N-Substituted-2-propynamides, Synth. Commun. 1993, 23, 2003-2010. (b) Safronova, L. P.; Medvedeva, A. S.; Klyba, L. V.; Bochkarev, V. N.; Andreev, M. V. Synthesis and Mass-Spectrometric Investigation of N-Aryl-3-trimethylsilyl-2-propyne-1-carboxamides. Russ. J. Org. Chem. 2000, 36, 184-190.

(11) (a) Awoonor-Williams, E.; Rowley, C. N. Evaluation of Methods for the Calculation of the p $K_{\mathrm{a}}$ of Cysteine Residues in Proteins. $J$. Chem. Theory Comput. 2016, 12, 4662-4673. (b) Bulaj, G.; Kortemme, T.; Goldenberg, D. P. Ionization-Reactivity Relationships for Cysteine Thiols in Polypeptides. Biochemistry 1998, 37, 8965-8972.

(12) When 1c (a nearly 1:1 diastereomeric mixture) was prepared in $\mathrm{CD}_{3} \mathrm{OD}$ at $\mathrm{rt}$, the solvent was evaporated under vacuum without heating, and the residue was analyzed by $\mathrm{NMR}$ spectroscopy in $\mathrm{CDCl}_{3}$ (including $\mathrm{NOE}$ experiments), both 4'-CH2 protons of both diastereoisomers appeared to have been partially exchanged with deuterium (see $\left.1 \mathbf{c}-d_{2}\right)$.

(13) (a) Kissane, M.; Murphy, M.; O’Brien, E.; Chopra, J.; Murphy, L.; Collins, S. G.; Lawrence, S. E.; Maguire, A. R. AdditionSubstitution Reactions of 2-Thio-3-Chloroacrylamides with Carbon, Nitrogen, Oxygen, Sulfur and Selenium Nucleophiles. Org. Biomol. Chem. 2011, 9, 2452-2472, and references therein. (b) Pil'o, S. G.; Brovarets, V. S.; Vinogradova, T. K.; Golovchenko, A. V.; Drach, B. S. Synthesis of New 5-Mercapto-1,3-Oxazole Derivatives on the Basis of 2-Acylamino-3,3-Dichloroacrylonitriles and Their Analogs. Russ. J. Gen. Chem. 2002, 72, 1714-1723. 
(14) For quite different alternatives to the use of maleimides and other activated double bonds, see: Toda, N.; Asano, S.; Barbas, C. F. Rapid, Stable, Chemoselective Labeling of Thiols with Julia-Kocienski-Like Reagents: A Serum-Stable Alternative to Maleimide-Based Protein Conjugation. Angew. Chem., Int. Ed. 2013, 52, 12592-12596.

(15) For related comparisons, see: Palkowitz, M. D.; Tan, B.; Hu, H.; Roth, K.; Bauer, R. A. Synthesis of Diverse N-Acryloyl Azetidines and Evaluation of Their Enhanced Thiol Reactivities. Org. Lett. 2017, 19, 2270-2273.

(16) It has been reported ( $\mathrm{Ref} 7 \mathrm{e}$ ) that, for the cleavage of $\mathrm{SCH}=\mathrm{CHCOPh}$ adducts, 30 equiv of Cys or of PhSH were required, but it did not work with $\mathrm{SCH}=\mathrm{CHCONHPh}$ adducts.

(17) (a) Blair, W. S.; Deshpande, M.; Fang, H.; Lin, P.-F.; Spicer, T. P.; Wallace, O. B.; Wang, H.; Wang, T.; Zhang, Z.; Yeung, K.-S. Preparation of Antiviral Indoleoxoacetyl Piperazine Derivatives. PCT Int. Appl. WO 2000076521 A1 20001221. (b) Wallace, O. B.; Wang, T.; Yeung, K.-S.; Pearce, B. C.; Meanwell, N. A.; Qiu, Z.; Fang, H.; Xue, Q. M.; Yin, Z. Preparation and Antiviral Activity of Substituted Piperazinyloxoacetylindole Derivatives. US Patent 20030069245 A1 20030410.

(18) For comparisons of azide reduction methods, see: (a) Bartra, M.; Romea, P.; Urpí, F.; Vilarrasa, J. A Fast Procedure for the Reduction of Azides and Nitro Compounds Based on the Reducing Ability of $\mathrm{Sn}(\mathrm{SR})_{3}{ }^{-}$Species. Tetrahedron 1990, 46, 587-594. (b) Amantini, D.; Fringuelli, F.; Pizzo, F.; Vaccaro, L. Selected Methods for the Reduction of the Azido Group. Org. Prep. Proc. Int. 2002, $34,109-147$.

(19) This compound is known. See the Supporting Information of: Healy, J.; Ekkerman, S.; Pliotas, C.; Richard, M.; Bartlett, W.; Grayer, S. C.; Morris, G. M.; Miller, S.; Booth, I. R.; Conway, S. J.; Rasmussen, T. Understanding the Structural Requirements for Activators of the Kef Bacterial Potassium Efflux System. Biochemistry 2014, 53, 1982-1992. 